\title{
DOSSIÊ
}

Sociologias, Porto Alegre, ano 17, no 39, mai/ago 2015, p. 60-109

\section{A Sociologia como uma Filosofia Prática e Moral (e vice versa)}

\section{Resumo}

Embora boa parte da sociologia contemporânea tenha um caráter político e moralizante, a sociologia da moral como tal permanece pouco desenvolvida. Diferentemente da sociologia da religião, da sociologia do conhecimento ou da sociologia das artes, a sociologia da moral não possui uma verdadeira tradição, ainda que os pais fundadores da disciplina tivessem, é claro, grande interesse sobre os temas da moral e da ética. Para desenvolver uma sociologia da moral que faça jus ao próprio nome, é preciso, antes de tudo, romper a barreira disciplinar entre a sociologia e a filosofia, e superar a desconfiança e resistência dos sociólogos para engajarem-se em um "pensamento liminar" construtivo. Neste artigo, pretendo tentar reconectar a sociologia à filosofia da moral e a filosofia da moral à sociologia. A tese que defendo é de que a sociologia dá continuidade, por outros meios, à venerável tradição da filosofia da prática e da moral. Como suas antecessoras, ela depende da defesa da "sabedoria prática" (Aristóteles) e da "razão prática" (Kant).

Palavras-chave: Sociologia moral. Ética descritiva. Neutralidade axiológica.

${ }^{*}$ Instituto de Estudos Sociais e Políticos - UERJ (Brasil) 


\section{Sociology as Practical and Moral Philosophy (and vice versa) ${ }^{1}$}

\section{Abstract}

While a good deal of contemporary sociology is political and moralizing, moral sociology as such remains largely underdeveloped. Unlike the sociology of religion, the sociology of knowledge or the sociology of arts, moral sociology does not have a real tradition, although the founding fathers had, of course, a strong interest in morality and ethics. To develop a moral sociology worthy of its name, one has first to break down the disciplinary barrier between sociology and philosophy and overcome the reticence and resistance of professional, critical and public sociologists to engage into some constructive "border thinking". In this article, I want to make an attempt to reconnect sociology to moral philosophy and moral philosophy to sociology. The thesis I want to defend is that sociology continues by other means the venerable tradition of practical and moral philosophy. Like its forebears, it stands and falls with a defense of "practical wisdom" (Aristotle) and "practical reason" (Kant).

Keywords: Sociology of morality. Descriptive ethics. Axiological neutrality.

Uma filosofia moral geralmente pressupõe uma sociologia Alasdair Maclntyre. After Virtue (p.23).

Cientistas sociais são filósofos da moral disfarçados Alan Wolfe. Whose Keeper? Social Science and Moral Obligation (p. 23).

${ }^{1}$ Este artigo é baseado em uma trilogia de cursos de pós-graduação que ministrei no Instituto de Estudos Sociais e Políticos (IESP-UERJ), no Rio de Janeiro: "Sociologia como uma Filosofia Prática (e vice versa)" [2012]; "Sociologia como Filosofia Moral (e vice versa)" [2013] e "Sociologia as Filosofia Política (e vice versa)". Agradeço aos estudantes que acompanharam os cursos, bem como a Raquel Weiss pelo convite a preparar o artigo.

•Tradução: Regina Vargas. 


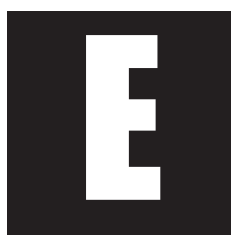

mbora boa parte da sociologia contemporânea tenha caráter político e moralizante, a sociologia da moral em si permanece, de modo geral, pouco trabalhada. Entretanto, tem ressurgido, recentemente, o interesse sobre a sociologia da moral, com esforços coordenados para institucionalizá-la como uma linha de investigação, tanto na Europa continental (centrada nos trabalhos de Honneth, Boltanski e Thévenot) como no mundo anglo-saxão (influenciado pelo trabalho de comunitaristas como Maclntyre, Taylor e Walzer, ou pelo realismo crítico de Bhaskar e Archer) $)^{2}$. Diferentemente da sociologia da religião, da sociologia do conhecimento ou da sociologia das artes, a sociologia da moral não possui uma verdadeira tradição, ainda que os pais fundadores da disciplina tivessem, evidentemente, grande interesse nos temas da moral e da ética ${ }^{3}$. Na medida em que exista um cânone, Émile Durkheim seria sua principal figura (embora sua obra "La Morale" tenha ficado inacabada). Max We-

\footnotetext{
${ }^{2}$ A recente publicação do "Handbook of Moral Sociology" (HITLIN e VAISEY, 2013) e "A Companion to Moral Anthropology" (FASSIN, 2012) revela um esforço coordenado para voltar a incorporar a ética às ciências sociais. A presente edição de Sociologias, a criação de um GT na ANPOCS sobre sociologia da moral e o fato de terem surgido recentemente três cursos distintos de pós-graduação sobre sociologia e antropologia da moral só no Rio de Janeiro (no Museu Nacional, ministrado por John Comerford, no IFCS/UFRJ por Alexandre Werneck e no IESP-UERJ por mim) são indícios fortes de que o Brasil está acompanhando a tendência.

${ }^{3}$ Como boa parte da literatura, utilizo indistintamente o termo moral e ética. Enquanto a ética tem origem grega, as origens da moral são latinas, com Aristóteles fazendo uma ponte entre

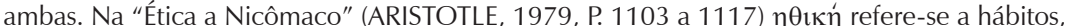
caráter, tradições populares, costumes, portanto, à moral, e tem uma conotação mais coletiva e social; $\eta \hat{\theta}$ os (com um "e" longo) refere-se à ética, portanto, à moralidade, e tem uma dimensão pessoal e subjetiva. No uso comum, a moralidade carrega elementos de moralismo, enquanto a ética envolve uma dimensão de deliberação pessoal e de responsabilidade subjetiva. A distinção de Hegel entre moralidade abstrata (Moralität) e vida ética concreta (Sittlichkeit) se sobrepõe à distinção anterior, mas não corresponde a ela. A ética grega trata do cultivo de virtudes e não de imperativos categóricos e normas universais, que são uma herança do estoicismo, do cristianismo e do kantismo.
} 
ber e sua paradoxal defesa da neutralidade axiológica viriam em segundo lugar, ainda que esta debilite a ética. Marx não deixou nenhum texto específico sobre a ética em si, e tampouco deixou claro se existe espaço no marxismo para uma moral que não seja subserviente à política. Afinal, como ele afirmou (MARX, 1969, p. 229), comunistas não pregam nenhuma moral. Georg Simmel, com seu "Einleitung in die Moralwissenschaft" (1991), possui dois volumes sobre ética, mas estes são pouco sociológicos e desconstroem a maior parte de seus fundamentos. Após a Segunda Guerra Mundial, Talcott Parsons, mais do que ninguém, deu continuidade à tradição durkheimiana, enfatizando a dimensão moral da vida social. Com a derrocada do estrutural-funcionalismo na década de 1960, a sociologia da moral passou a hibernar ${ }^{4}$. Pierre Bourdieu certamente produziu uma sociologia da moralidade, mas não uma sociologia moral. Como tudo mais, ele explica a moral sociologicamente, mas não deixa muito espaço para uma reflexão independente sobre a moral. Em contrapartida, tem-se a teoria da ação comunicativa e a ética do discurso de Jürgen Habermas, apesar de a maioria dos sociólogos o considerarem um filósofo.

Pode-se defender com facilidade a ideia de que os "pais fundadores" de nossa disciplina, não apenas Marx, Weber e Durkheim, mas também Parsons e Bourdieu, os quais, ao contrário de nós, estavam profundamente imersos na filosofia e conheciam seus clássicos, tinham plena consciência das dimensões morais da vida social bem como dos

${ }^{4}$ Há tão poucas publicações sobre sociologia da moral na segunda metade do século XX, que elas podem facilmente ser listadas em uma nota de rodapé. Na França, tem-se Gurvitch (1968); Isambert, Ladrière e Terrenoire (1978); Isambert (1982); Ladrière (2001); nos EUA, Haan, Bellah, Rabinow e Sullivan (1983) tentaram reviver a investigação normativa, mas sem sucesso. Foi preciso esperar por um renascimento na filosofia moral e política nos anos 1980 (Rawls, o debate entre liberalismo e comunitarismo etc.) antes que a sociologia colocasse a moralidade de volta em sua agenda de pesquisa. Para o estado da arte em filosofia moral. Ver Canto-Sperber (1996, com 250 colaboradores e 1700 páginas, repartidas em 2 colunas). 
pressupostos e implicações normativas da nova disciplina. Apesar de sua declaração em contrário, eles bem sabiam que a sociologia que estavam propondo situava-se em uma longa tradição, e explicitamente tomavam partido: Marx tentou combinar Aristóteles, Kant e Hegel em uma revolucionária filosofia da história, Durkheim estava sabidamente mesclando Aristóteles e Kant em sua ciência da moral, enquanto Weber, colocando de escanteio 2000 anos de filosofia moral, sociologizava a marteladas. Parsons, por sua parte, rejeitou o consequencialismo utilitarista e buscou, por meio de uma síntese de Kant e da ética cristã, restaurar um sistema comum de fins últimos. A despeito de sua adesão à razão prática e para não ser demasiadamente associado à teoria marxista da justiça, Bourdieu descreveu a si mesmo como um pascaliano. De qualquer modo, sem referência aos clássicos de nossos fundadores, suponho que estes não podem ser corretamente entendidos.

Para desenvolver uma sociologia moral que faça jus a seu nome, é preciso antes romper a barreira disciplinar entre a sociologia e a filosofia e superar a desconfiança e a resistência por parte dos sociólogos profissionais, dos sociólogos críticos e daqueles comprometidos com uma sociologia pública para que possa haver um engajamento com um "pensamento liminar" construtivo ${ }^{5}$. Embora, provavelmente, quase todos concordariam que a sociologia acarreta um projeto normativo, fundado em uma visão de mundo liberal-comunitária algo nostálgica, poucos estariam de fato dispostos a explicitar esse projeto e iniciar uma indagação filosófica sobre seus fundamentos normativos ${ }^{6}$. Preparar o terreno e testar as fundações, diriam eles, cabe melhor aos filósofos, engenheiros e construtores. Não

${ }^{5}$ O retumbante sucesso da "sociologia pública" (ver BURAWOY, 2005 e vários livros sobre o tema) sugere que é mais fácil romper as fronteiras entre a academia e o ativismo do que aquela entre a sociologia e a filosofia.

${ }^{6}$ A sociologia nasce como uma filosofia social, segundo François Dubet (2009, p. 15) e, exagerando sua suposição, acrescenta, como uma teologia da sociedade (id.: 8). Embora Comte visse a si mesmo, indubitavelmente, como um alto sacerdote da sociedade e concebesse a 
é trabalho para os cientistas sociais. Da mesma forma, embora a maior parte acolhesse a ideia de que a sociologia da moral é em si relativamente inseparável de uma posição normativa, eles não quereriam escutar que, para entender adequadamente essas posições normativas, teriam de conhecer a tradição clássica da filosofia moral e também acompanhar as discussões sobre a filosofia moral contemporânea.

Neste artigo, pretendo tentar reconectar a sociologia à filosofia moral e a filosofia moral à sociologia. A tese que pretendo defender é de que a sociologia dá continuidade, por outros meios, à venerável tradição da filosofia prática e moral. Como suas antecessoras, ela depende da defesa da "sabedoria prática" (Aristóteles) e da "razão prática" (Kant). Se pretendo romper com a solução de continuidade, não é por pensar que a sociologia tem pouco a oferecer, mas por estar convencido, como Chernillo (2013, p. 2), de que se pode fazer mais e melhor teoria social (itálico no original) ao permitir-se dialogar com questões filosóficas nas fronteiras da sociologia. Não devemos, absolutamente, deixar as questões filosóficas de nossa disciplina aos filósofos profissionais. Com algumas notáveis exceções - que se podem contar em uma mão: Habermas, Honneth, Ricoeur, Taylor e Maclntyre - eles conhecem pouco da sociologia e não se importam muito com ela. Fosse de outra forma, provavelmente não construiriam suas visões normativas como castelos no ar. Ao contrário, deve-se tomar a liberdade de explorar, com toda a modéstia, os fundamentos filosóficos da sociologia e "produzir metateoria", não tanto para se permitir os sabores da erudição, mas como uma propedêutica para sólidas construção teórica e pesquisa empírica sobre as dimensões normativas do mundo social.

sociologia como uma sociolatria, não se pode dizer o mesmo de outros clássicos. Isso posto, Dubet mostra que os sociólogos não são apenas analistas da sociedade, mas também seus promotores. Do mesmo modo, a sociedade não é apenas um objeto social a ser investigado, é também um projeto moral e moderno que visa criar uma sociedade de indivíduos, com base no reconhecimento de valores comuns de igualdade, liberdade e solidariedade. 


\section{O que vem a ser Sociologia Moral?}

A sociologia moral não é uma especialidade da sociologia, como a sociologia dos esportes ou a sociologia da administração, por exemplo. Ela não se refere a um setor da vida social e sim a uma perspectiva sobre a vida social que desvela e revela uma ética onde ela brota, embora permanecendo escondida (ISAMBERT; LADRIÈRE; TERRENOIRE, 1978). Como tal, é parte integrante de uma sociologia geral que busca inter-relacionar sistematicamente estruturas sociais, cultura e práticas dentro de um marco teórico que proporcione uma resposta coerente para as três questões fundamentais da teoria social: O que é ação social? Como é possível a ordem social? Quais são as condições para a mudança social? Mais próxi$\mathrm{ma}$, nesse sentido, da sociologia da cultura e de sua defesa da relativa independência da cultura (ALEXANDER, 1990, p. 1-30), a sociologia moral é uma perspectiva geral que traz à luz a dimensão moral da vida social e afirma que princípios, normas e valores não são apenas regulatórios, mas também constitutivos. São constitutivos não só de um certo domínio de ações, mas da própria vida social. Isso não significa que todas as ações são per definitionem ações morais (a maior parte de nossas ações econômicas não são nem morais nem imorais, tampouco nossa vida sexual é, hoje, julgada em termos morais, etc.), mas que a moral, os costumes e a ética estão invariavelmente implicados na ação, na ordem e na mudança social.

Cada ação, não importa quão racional ou emocional, rotineira ou estratégica, está cercada por um horizonte normativo que fornece os princípios, fins e valores que a definem e direcionam. De modo similar, as instituições - não importa quão sistêmicas sejam - possuem um ideal fundador que molda sua organização e seus objetivos, e é instrumental na coordenação das ações de seus membros. Mesmo os mercados financeiros estão imersos em uma economia moral e é graças a essa infraestrutura moral que seus excessos podem ser julgados e criticados. Se a mudança 
social é possível, é também porque as estruturas normativas que sustentam as instituições, sejam tomadas isoladamente ou em conjunto, variam com o tempo. Se a mudança social é necessária, é, entre outras razões, porque os interesses ideais de ontem entram em conflito com os interesses materiais da atualidade, ou vice versa. Quando os atores consideram que os sistemas sociais, instituições e práticas existentes não só estão em desacordo com seus interesses concretos, mas também traem suas promessas morais e prejudicam suas aspirações existenciais a uma vida satisfatória, a mudança social é iminente.

Por analogia com a famosa distinção de Jeffrey Alexander (2003, p. 11-26) entre a sociologia da cultura e a sociologia cultural, podemos fazer uma distinção entre a sociologia da moral e a sociologia moral. Enquanto a primeira assume a moralidade como algo que precisa ser explicado por fatores sociais (moralidade como variável dependente), a última investiga como a moralidade produz, constitui e regula as ações, instituições e estruturas sociais (moralidade como uma variável independente) ${ }^{7}$. Certamente, a linguagem de variáveis dependentes e independentes é redutiva e não muito apropriada para a análise da interdependência generalizada e da mútua constituição da moral e da vida social. Como se tivéssemos de escolher entre uma simples alternativa: Explicar os fatos morais pela sociedade ou os fatos sociais pela moralidade? (PHARO, 2004, p. 45).

\footnotetext{
${ }^{7}$ Pode-se estender a analogia à religião (e à política), mas talvez com uma notável diferença axiológica: enquanto a maior parte dos sociólogos da religião argumenta que uma sociologia da religião não é uma sociologia religiosa (ou política) os sociólogos da moral sustentariam que a sociologia da moral está amarrada a uma posição normativa e se esforçariam para explicitar isso. No entanto, não se deve identificar sociologia da moral com uma sociologia moralizante, mas sim com uma divisão descritivo-normativa da sociologia geral.
} 
Vale, contudo, distinguir duas linhas concorrentes na tradição sociológica que investiga o papel da moralidade e da ética na vida social ${ }^{8}$. $\mathrm{Na}$ primeira linha, com antecedentes que remontam aos mestres da suspeita modernos (Machiavel, Marx, Freud e Nietzsche), encontramos autores como Weber, Elias, Adorno, Althusser, Foucault e Bourdieu, nas tradições materialista, estruturalista, desconstrutivista e crítica que têm na ética um epifenômeno - e, por vezes, até mesmo um disfarce - para interesses obscuros e brigas de poder. Como Bourdieu (1994, p. 147167) questionou enfaticamente: Quem tem interesse em ser ou parecer desinteressado (désinteressé)?

Nas outra linha, com antecedentes que remontam aos Profetas da transfiguração (Agostinho, Espinoza, Kant, Hegel), encontramos autores de tradições idealista, racionalista, pragmatista e hermenêutica, como Durkheim, Mauss, Weber, Mead, Parsons, Habermas, Honneth e Boltanski. Weber figura em ambas as listas. Dependendo do que se lê ("Ciência como Vocação" ou a "Ética Protestante") e também de como é lido, ele pode tanto parecer um austero nietzschiano com inclinações existencialistas como um sofisticado neokantiano na tradição humanista ${ }^{9}$. Weber é, de fato, eclético, mas, ao fim das contas, tudo depende do que se faz com seu ardente apelo por neutralidade axiológica. Mais adiante, argumentarei enfaticamente contra esta posição, a qual considero um sério obstáculo a uma sociologia moral.

\footnotetext{
${ }^{8}$ Pharo (2004) faz uma distinção similar, mas organiza suas tradições de outra forma. Ele distingue as teorias socioculturais da moralidade (Durkheim, Parsons, Bourdieu, Berger e Luckmann) das teorias da ação (Weber, Garfinkel, Habermas e Boltanski). Como pretendo desenvolver uma sociologia moral como uma sociologia cultural da ação, não tenho escrúpulos em juntar Durkheim, Weber, Parsons, Garfinkel, Habermas e Boltanski no mesmo grupo.

${ }^{9}$ Para leituras ressonantes de Max Weber que minimizam o forte tom nietzschiano em sua obra, ver Schluchter (1991, I: Parte 2) e Sell (2013).
} 
Como a moralidade é parte da cultura, a sociologia moral é, por definição, uma sociologia cultural. Como a cultura, a moralidade constitui um sistema referencial de ação relativamente autônomo. O que distingue moralidade de cultura é sua relação intrínseca com padrões normativos de avaliação, julgamento e justificação em termos de entendimentos sobre o que é certo e errado, bom e mau, com valor e sem valor, justo e injusto (SMITH, 2003, p. 8). Enquanto conjunto de visões normativas que fornecem padrões de avaliação (princípios, valores e normas) pelos quais as ações (próprias e de outros) podem ser julgadas, a moralidade é parte de uma ordem cultural compartilhada que se institucionaliza em práticas sociais estruturadas ${ }^{10}$. Como tal, ela existe fora das pessoas (id.). Uma vez que essas perspectivas culturais são aprendidas e internalizadas em e através de processos de socialização, a moralidade também existe dentro das pessoas (ibid.) como um conjunto de padrões de comportamento correto que define, orienta e regula suas ações a partir de seu ego. Tais padrões podem ser formulados reflexivamente, seguidos de forma semiconsciente ou vagamente percebidos, mas não expressos, como é o caso dos sentimentos morais (como, compaixão, orgulho, ressentimento etc.).

Seguindo a famosa détournement (derivação) de Bourdieu, da distinção de Espinoza entre natura naturans e natura naturata, poderíamos afirmar, com a tradição durkheimiano-weberiana da sociologia moral, que a moralidade é uma estrutura estruturante, a qual revela o valor do mundo; e, com a tradição weberiano-marxista da sociologia da moralidade, que ela é uma estrutura estruturada, a qual expressa relações de

\footnotetext{
10"Norma, princípios e valores" é uma simplificação que utilizo para referir-me a proposições normativas de diversos tipos: princípios, normas, imperativos, moral, modos, costumes, máximas, regras, valores, virtudes, crenças e, mesmo, sentimentos etc. Seria necessário um filósofo analítico e, portanto, toda uma vida para separá-los, explicá-los e desenhar um mapa completo de suas inter-relações.
} 
força e contribui para a reprodução da sociedade como um sistema de dominação. Enquanto a conexão com a cultura permite conceber a moralidade como um sistema referencial coletivo internalizado, o qual estrutura e regula ações conforme padrões, sua relação com estruturas sociais, interesses materiais e relações de produção sugere que a invocação do bem comum e do interesse geral, a qual caracteriza a vida moral, está enraizada em determinados modos de viver e expressa, através de estratégias de universalização e de idealização, os interesses e ideais de determinados grupos e estratos portadores (classes, propriedades, nações etc.). Do ponto de vista da sociologia da moral, os posicionamentos morais podem e devem ser explicados em termos de posições sociais contidas na estrutura social e de seus respectivos discursos. Nesse sentido, a sociologia da moral pode ser considerada uma formalização da sociologia popular: Eles diriam/fariam isso, não? (SAYER, 2005, p. 6). Para uma sociologia cultural que busca manter um vínculo entre práticas e mudança social, a questão é: de que modo princípios, normas e valores podem ser simultaneamente uma condição e uma consequência da ação social. Para solucionar este enigma, sugiro ser necessária uma referência à normatividade e à moralidade.

\section{2. Ética Descritiva}

Os filósofos consideram que a redução sociológica da moralidade a um conjunto de convenções, costumes e comportamentos social, cultural e historicamente variáveis, esvazia totalmente o juízo moral ${ }^{11}$. Ao sugerir que a moralidade sempre ocorre no plural, a sociologia introduz

\footnotetext{
${ }^{11}$ Foi como se a moral tivesse se revelado repentinamente no sentido original da palavra, como um conjunto de tradições, hábitos e costumes, que poderia ser trocado por um outro conjunto sem mais dificuldade do que a implicada em mudar os modos à mesa de um indivíduo ou um povo (ARENDT, 1994, p. 740).
} 
uma boa dose de relativismo e ceticismo no debate sobre a moral. Vem à mente, então, a exclamação de Pascal: Um meridiano decide a verdade [...] Curiosa justiça: um rio a limita! Verdade deste lado dos Pirineus, erro do outro lado (PASCAL, 1954, § 294). Para os filósofos da moral, que procuram um critério avaliador que seja idealmente universal e válido para qualquer comunidade moral concebível, falar sobre múltiplas moralidades é necessariamente problemático. Podemos imaginar, seguindo Steven Lukes, que eles querem apresentar aos sociólogos da moral uma questão meta-ética fundamental: Diversidade da moral é diversidade do quê? (LUKES, 2013, p. 558). Para responder adequadamente e sem subterfúgios a essa questão, há que formular critérios metaéticos que tornem possível a qualificação de qualquer ato como moral, como imoral ou como moralmente neutro.

Embora esta reflexão sobre a natureza das propriedades éticas dos julgamentos morais (o que torna moral um julgamento?) seja indubitavelmente filosófica, pode-se torná-la mais sociológica ao abrir a questão aos próprios atores. Na medida em que os atores reflitam sobre os critérios que utilizam para justificar seu próprio comportamento ou criticar o de outros, cada ator bem pode ser considerado um filósofo. Na verdade, não há qualquer razão para rejeitar uma sociologia da filosofia ou, melhor dizendo, de filósofos leigos em situações de ações cotidianas que são submetidas a imperativos de justificação (BOLTANSKI e THÉVENOT, 2000). $\mathrm{Na}$ vida cotidiana, os atores avaliam, julgam, criticam outros o tempo todo. Uma vez que se comece a prestar atenção ao papel dos argumentos filosóficos em situações de ação rotineiras, se descobrirá que os atores são dotados de um 'senso crítico' e que utilizam constantemente uma linguagem moral para denunciar injustiças de todos os tipos. É suficiente ouvir atentamente o incessante rumor que atesta a indignação, a dor e a inquietação causadas pelo sentimento de injustiça, que manifesta a capacidade das pessoas de ativar seu senso de equidade (BOLTANSKI, 1990, p. 130). 
Sociologias, Porto Alegre, ano 17, no 39, mai/ago 2015, p. 60-109

Os sociólogos fazem o mesmo, contudo, não tanto como sociólogos - o dogma da neutralidade ética os proíbe de tomar partido -, mas como atores. Uma sociologia reflexiva, na qual o sociólogo observa e descreve, explica e compreende os argumentos normativos de atores comuns, inclusive os seus próprios, não só é uma parte necessária da vigilância epistemológica (BOURDIEU; CHAMBOREDON e PASSERON, 1973, p. 94-106); também permite ver que a sociologia defronta-se com o posicionamento moral tanto como um recurso (os pressupostos morais da sociologia) quanto como um "tema" em si mesmo (os posicionamentos morais dos atores). A moralidade está sempre lá como um contexto moral não questionado e continuamente reafirmado (sociologia como um empreendimento liberal-comunitário moderno) e como um horizonte moral (as visões normativas que inspiram e motivam os atores). Uma vez que a denominação não descarta a investigação das interconexões entre ambas, se poderia denominar a primeira moralidade profissional da sociologia e a segunda sua moralidade leiga. Com os conceitos sociológicos circulando do mundo da vida para a academia e vice versa, ambas estão profundamente entrelaçadas. A dupla hermenêutica é, de fato, tão profunda e a reflexividade institucional tão intensa, que é difícil dizer onde uma começa e a outra termina (GIDDENS, 1981, p. 1-17).

Os filósofos da moral vivem em um mundo ideal e perfeito em que os julgamentos são sempre plenamente explicitados e as pessoas comportam-se racionalmente e moralmente. Seu interesse reside em questões puramente normativas, conceituais e histórico-filosóficas: Quais são os critérios da moralidade? Como funciona o senso de justiça? É possível ser um cognitivista em ética? Como se pode justificar uma determinada norma? Qual a relação entre virtudes e valores, valores e normas ou valores e sentimentos morais? A justiça tem prioridade sobre o bem? Como alguém deve se portar em uma determinada situação? O que Aristóteles

http://dx.doi.org/10.1590/15174522-017003903 
queria dizer com phronesis? Justifica-se a crítica de Hegel a Kant? Qual a posição originária de Rawls e como ela se compara à situação ideal de fala de Habermas? Pode a crítica ser transcendente ou ela tem sempre de ser imanente? Para os sociólogos, que já não mais são formados em filosofia, essas discussões filosóficas com frequência parecem não-substantivas, técnicas, e mesmo, sem sentido.

De uma perspectiva sociológica, os filósofos são perfeccionistas. Lidam com atores ideais em mundos ideais, não com contextos reais e situações confusas. Estão, acima de tudo, preocupados com questões normativas e os exemplos da vida cotidiana que referem, ou mesmo inventam (especialmente se são formados na tradição analítica) revelam que eles não se importam muito com descrições ou explanações. Os sociólogos, por sua vez, evitam enumerações de virtudes, enunciados sobre o bem ou elaborações sobre o justo. Em lugar disso, focam no negativo e no mau (racismo, sexismo, colonialismo), denunciam injustiças (desigualdade e exploração) e desvelam patologias sociais (alienação, desencantamento e anomia), deixando a justificação explícita de suas críticas, normas e utopias para os filósofos (BENHABIB, 1986). E, afinal, não somos todos contra exploração, estupro e assassinato?

Para fazer a transição da filosofia moral para a sociologia moral como uma forma de investigação moral (BELLAH, 1983), é preciso trazer de volta a filosofia para o mundo real e investigar empiricamente como os atores ponderam, pensam, avaliam, justificam e atuam moralmente em situações de ação comuns. Essa transição do normativo para o empírico só é possível se a filosofia não for contraposta à sociologia, e sim integrada a esta, formando algo como uma "ética descritiva" (algo similar, talvez, à "metafísica descritiva"). Esse intento estaria na interseção da ética (porque implica discussões filosóficas sobre "o bem" e "o justo" e também conhecimento da tradição da filosofia moral) com a sociologia (porque 
descreve, compreende e explica o senso moral das pessoas em situações reais de ação).

O que é necessário aqui é uma boa articulação entre i) descritivo e prescritivo, ii) externo e interno, iii) posições de observador e de ator:

(i) A partir dessa perspectiva dialógica, é preciso, primeiro, estudar as prescrições normativas de filósofos, para melhor descrever a dimensão normativa da vida social. Ao longo da história, os filósofos desenvolveram linguagens complexas e perspectivas elaboradas do bem e do justo em sociedades bem organizadas (MACINTYRE, 1966; TAYLOR, 1989; ver também a última seção deste artigo). Os sociólogos devem estudar esses sistemas filosóficos como repertórios morais que fazem parte da cultura ocidental ${ }^{12}$. Parodiando uma célebre frase de Paul Ricoeur - explicar mais para entender melhor (RICOEUR, 1986, p. 22) -, poderíamos dizer que o propósito deste desvio através da filosofia é prescrever mais para descrever melhor e, também, inversamente, descrever mais para prescrever melhor e fundar o julgamento no senso crítico dos atores.

(ii) em seguida, é preciso também superar a oposição entre um entendimento interno dos atos morais (internalismo) e uma observação externa dos fatos morais (externalismo). Na verdade, externalismo supõe internalismo, observação supõe entendimento, entendimento supõe julgamento: Só entendemos um ato discursivo se soubermos o que o torna aceitável. [...] Entender as razões (da ação) implica em si uma avaliação (HABERMAS, 1981, p. 168-169). Isso ocorre,

\footnotetext{
${ }^{12}$ Alguém poderia objetar: "Você poderia ter submetido o cânone ocidental a uma crítica pós-colonial". No entanto, se eu enfatizo a cultura ocidental é simplesmente por ter conhecimento insuficiente de outras culturas e seus sistemas filosóficos.
} 
porque, como assinalaram repetidamente semanticistas sociológicos (PHARO, 2004, p. 48-84), neowittgensteinianos ( $\mathrm{LOUCH}, 1966$, p. 50-60) e etnometodólogos (JAYYUSI, 1991, p. 227-251), antes que se possa observar e registrar fatos morais, é preciso ser capaz de reconhecê-los, o que pressupõe pelo menos algum tipo de "criteriologia normativa". Sem reconhecimento da moral, sem um julgamento implícito e uma avaliação dos fatos sociais, tampouco haverá cognição dos fatos morais. O normativo reside no descritivo e o descritivo no normativo. A quaestio facti não pode ser separada da quaestio iuris. Para a ética descritiva, portanto, métodos objetivos, não avaliativos, neutros não são uma opção.

(iii) Finalmente, e associado ao anterior, é preciso também unir a perspectiva de primeira pessoa, do filósofo normativo, à perspectiva de terceira pessoa, do sociólogo observador. Os filósofos assumem uma perspectiva performativa e buscam fundamentar racionalmente seus julgamentos, através de argumentação moral, deliberação e justificação. Com frequência, falam em seu próprio nome, mas, por meio de argumentos morais sustentados com interlocutores reais ou imaginários, elevam-se da perspectiva de primeira pessoa para a perspectiva universal de um juiz imaginário (o tribunal da razão de Kant) que incorpora a perspectiva da humanidade como tal. Os observadores sociológicos normalmente evitam julgar seus sujeitos de observação. Ao invés de avaliar criticamente suas posições de um ponto de vista moral, eles tentam compreendê-las e explicar seu comportamento com referência a sua comunidade e ao discurso moral da mesma. De um modo bem weberiano, eles o fazem tornando explícito o universo moral específico da comunidade nativa. Interpretar, explicar e compreender os posicionamentos morais dos sujeitos, sem julgá-los, é o que recomenda e exige a observação participante. 
Sociologias, Porto Alegre, ano 17, no 39, mai/ago 2015, p. 60-109

Através da fusão da posição do filósofo (e, lembremos, com Gramsci, que "cada homem é um filósofo") com a posição do sociólogo, podemos alcançar uma hermenêutica explicitamente normativa da "avaliação participante" em que o sociólogo tem de julgar as avaliações daqueles que observa para compreendê-los melhor - a eles e seu universo moral. Uma vez que se tenha integrado filosofia e sociologia em uma etnografia da moral (sic), pode-se também atacar o dogma weberiano da neutralidade axiológica (WEBER, 1988a, b) e propor uma sociologia normativa que não é nem relativista nem decisionista, mas faz total justiça às concepções normativas e intuições dos próprios atores.

\section{Contra a Neutralidade Axiológica}

Caso se queira desenvolver uma sociologia moral como uma "investigação moral", que interprete, explique e descreva o senso moral do ator, é preciso, antes de tudo, remover um tremendo obstáculo: Wertfreiheit e se perguntar se a defesa de Weber da neutralidade axiológica é de fato axiologicamente neutra. Sei que faz parte da doxa sociológica não inserir a avaliação subjetiva do próprio pesquisador no objeto estudado. A pesquisa deve ser objetiva e neutra, não parcial e tendenciosa. Certamente, quando se está ensinando, deve-se abster de emitir juízos e de doutrinação e não se comportar como um profeta remunerado em sala de aula (WEBER, 1988c, p. 580). Mesmo um marxista deve ser capaz de lecionar Spencer, Pareto ou Weber para seus alunos, sem usar de ironia, depreciativos e desfeitas. Mas o que, à primeira vista, parece uma posição razoável, representa, de fato, se for abordada como uma doutrina ética, uma posição um tanto extrema na história da filosofia moral. Não é preciso ir tão longe como Leo Strauss (1953, p. 35-80) e acusar Weber de "niilismo" (ainda que seja um "nobre niilismo"), mas que sua defesa da neutralidade 
está longe de ser neutra é evidente para qualquer pessoa com algum conhecimento de história da ética e filosofia moral. O apelo de Weber por Wertfreiheit, que Talcott Parsons judiciosamente traduziu como "freedom to judge" (livre de julgamento), é inseparável da denúncia indiscriminada de Nietzsche da ética como ressentimento disfarçado. Neutralidade é, portanto, não o que parece, mas seu oposto: irracionalismo, relativismo, decisionismo (VANDENBERGHE, 2005). Não uma posição consensual, nem uma de bom senso, mas antes uma posição polêmica que introduz conflito e tensões entre colegas e desmerece seu compromisso profissional com os modernos valores liberal-comunitários ${ }^{13}$.

Mas, antes de avançar para a refutação de uma série de dualismos (fato/valor; ser/dever ser; objetivo/subjetivo; positivo/normativo) associados ao Wertfreiheit, devo primeiro louvar a prática científica de Weber enquanto historiador e sociólogo clássico que demonstra, como talvez nenhum outro depois dele, o papel constitutivo de ideias, valores e crenças no decorrer da história universal. Se "A Ética Protestante" é um clássico, não é tanto em razão de sua tese central - que tem sido contestada por historiadores desde que foi publicada em 1904 (FISCHOFF, 1944) -, mas porque, como um trabalho primordial na tradição alemã Geisteswissenschaften, tornou-se nosso melhor exemplo de sociologia interpretativa. Sua reconstrução do ethos (ou habitus moral) dos primeiros empreendedores protestantes e seu papel determinante não só na ascensão do capitalismo do Norte, como também, de forma mais geral, na emergência do racionalismo ocidental, torna a obra um exemplo paradigmático da e para a sociologia moral.

\footnotetext{
${ }^{13} \mathrm{O}$ apelo entusiasmado de Nathalie Heinich (2006) por uma ciência da moral que não fosse uma sociologia moral invoca Weber continuamente, mas de forma polêmica, para atacar seus oponentes no campo. A distinção entre os valores do analista e aqueles dos atores é meramente analítica e se desfaz no momento em que se analise o sociólogo não como um cientista, mas como um ator engajado em um campo de batalha científico.
} 
Como sempre ocorre em relação a Weber, o problema não está no que ele faz, que é exemplar, mas no que ele diz sobre o que faz. Entre a teoria e a prática, existe uma tensão significativa e, com muita frequência, mesmo uma flagrante "inconsistência $T / P$ " que pode ser dialeticamente solucionada, se nos ativermos às práticas e desenvolvermos a teoria que é imanente a elas ${ }^{14}$. Tem sido apontado, muitas vezes, que Weber prescreve o individualismo metodológico no capítulo de abertura de "Economia e Sociedade", mas nos capítulos substanciais do mesmo livro pratica uma forma de estruturalismo não muito distante das descrições encontradas na historiografia marxista. Da mesma forma, no âmbito metodológico, os tipos ideais (Idealtypen), como são geralmente construídos e utilizados por historiadores comparativos, estão adequados; no entanto, a justificação epistemológica dada por Weber é problemática. O método dos tipos ideais, apesar de metodologicamente robusto, é fraco do ponto de vista epistemológico. Lembra nominalismo e convencionalismo e esquece-se de reconectar as categorias do analista às categorias dos atores - como se o analista pudesse impor livremente suas categorias, ao analisar, por exemplo, a vida social de um restaurante como se fosse uma peça de teatro, embora os atores acreditem estar fazendo algo mais. O uso de ironia, sarcasmo e sátira em uma análise assim goffmanniana não é problemático apenas do ponto de vista epistemológico, mas, talvez, também do ponto de vista moral (embora eu não queira, decididamente, policiar textos em relação a sua correção moral).

Se passarmos da epistemologia para a ética, da abordagem de Weber dos tipos ideais (démarche idéal-typique) para aquilo que, seguindo

${ }^{14}$ Para uma investigação dialética e resolução das inconsistências de Teoria-Prática ou T/P, ver Bhaskar (1993, capítulo 2). 
Alain Caillé (no prelo, cap. 12), poderíamos denominar a sua dialética dos "tipos idealistas" (démarche idéaliste-typique), a qual confronta os valores que uma sociedade declara com aqueles que ela institucionaliza, encontramos uma fissura similar entre teoria e prática, mas agora na forma de uma inconsistência teórico-axiológica. Aqui, também, a defesa da neutralidade valorativa faz sentido no nível prático (um sociólogo pacifista deveria ser capaz de ministrar um curso sobre violência, e um agnóstico deveria ser capaz de pesquisar o ethos calvinista nos países do norte etc.), mas dificilmente poderia ser sustentada reflexiva e filosoficamente sem que se incorresse em contradições performativas e paradoxos autorreferenciais. De novo, há uma desconexão, mas desta vez entre os valores dos atores (que julgam o tempo todo) e aqueles do analista (que se abstém de julgar, por ser relativista e/ou decisionista). A desconexão entre a moralidade leiga e a profissional é parte de uma abordagem dualista e disjuntiva que, em lugar de integrar, contrapõe fatos a valores.

O problema com essa distinção fato/valor e a cascata de dualismos que dele decorre - ser/dever ser, razão/emoção, ciência/ideologia, ciência/ ética, positivo/normativo, objetividade/subjetividade (SAYER, 2011, p. 30) - é duplo: conduz não só a expulsar da ciência os valores, como também, embora de modo menos perceptível, a expulsar dos valores a ciência ou a razão (SAYER, 2011, p. 28; 2005, p. 214) ${ }^{15}$. Para que seja possível uma sociologia moral como um campo da ética descritiva, enquanto continuação explícita da filosofia moral por outros meios, ela precisa desconstruir as oposições e reconectar ciência a valores e valores à razão. A expulsão

\footnotetext{
${ }^{15} \mathrm{Em}$ Weber, a dupla expulsão dos valores e sua redução a meros sentimentos e afetos seguem par a par com a expulsão das emoções da razão e sua consequente redução a expressões de preferência ou atitude. Em oposição a Weber e seus colegas emotivistas, Barbalet (2001, p. 29-61) argumenta que as emoções podem ser racionais e demonstra que o funcionamento da razão instrumental pressupõe o trabalho de "emoções de fundo" (como satisfação no próprio trabalho, orgulho do próprio talento etc.).
} 
Sociologias, Porto Alegre, ano 17, no 39, mai/ago 2015, p. 60-109

dos valores da ciência através da purificação axiológica é mal concebida desde o princípio. A ciência pode ser qualquer coisa, menos isenta de valores. Com isso, não quero dizer que a ciência é um "vale-tudo", mas, usando (i) teoria crítica, (ii) fenomenologia e (iii) linguagem comum da filosofia, pretendo argumentar que ciência, percepção e descrição estão impregnadas de valores.

(i) Como exercício de sociologia crítica reflexiva, quero assinalar, em primeiro lugar, juntamente com teóricos críticos (como Horkheimer, Marcuse e Habermas) que a concepção de neutralidade axiológica da ciência é uma das principais bases da visão de mundo do "cientista" na teoria tradicional ("ciência como ideologia") e que esta concepção intervencionista, pragmática e instrumentalista do conhecimento ("ciência como técnica e ideologia") é tipicamente ocidental e tipicamente moderna, embora hoje tenha se tornado universal. A separação entre ciência e senso comum - science et conscience, nos termos de Edgar Morin - marca uma época e uma civilização. A aplicação sistemática de ciência e tecnologia modifica o conteúdo ético do mundo da vida e destrói valores tradicionais. Ao encobrir a "dominação" sobre a natureza e a concomitante destruição de valores tradicionais sob a linguagem neutra da ciência e da tecnologia, que precisa ser entendida por um chinês como correta (WEBER, 1988a, p. 155), o positivista pode camuflar sua visão tecno-lógica do mundo como universal. Ao afirmar que só busca a verdade em si mesma, o cientista não está propriamente mentindo, mas sim jurando lealdade à bandeira da verdade, embora sem referir o país que ela representa (GOULDNER, 1973, p. 65).

(ii) Com os fenomenólogos (como Husserl, Heidegger e Scheler), podemos mostrar, além disso, que a "extração" dos valores da "visão de mundo natural" e a imposição de uma "visão de mundo 
naturalista" para substituí-la dificilmente poderiam ser consideradas neutras. A conjunção entre naturalismo e positivismo, que caracteriza a perspectiva científica, desumaniza o mundo e o despoja de seus Eigenvalues. Quando Weber implora ao cientista para não impor ao mundo seus próprios valores, ele esquece que a constituição do mundo é sempre um tema axiológico. Sua exigência de remover valores da ciência depende e vem depois da remoção de valores do mundo da vida. Antes mesmo que possamos perceber o mundo, atribuímos valor a ele, e é por atribuir-lhe valor que o podemos perceber. Não existe percepção (Wahrnehmung) sem valoração (Wertnehmung) ou, passando de Max Scheler (1980) para Axel Honneth (2005), não há cognição (Erkennung) sem reconhecimento (Anerkennung) de princípios, normas e valores.

(iii) Finalmente, com os filósofos neowittgensteinianos (como Winch e Louch) e os etnometodólogos (como Garfinkel, Jayyusi e Rawls), podemos com facilidade sustentar que os fatos científicos não só são "impregnados de teoria" como são também "impregnados de valores". Os valores não são apenas regulatórios, são constitutivos do próprio fato observado e descrito. A descrição e a valoração dos fatos não são duas operações distintas, mas se mesclam. Ao descrevermos uma ação como sendo de certo tipo (por exemplo, uma promessa, uma ameaça), ou ao utilizarmos "conceitos densos" afirmando que ela foi "mal" ou "bem" sucedida, não a descrevemos primeiro para depois julgar, mas, ao julgá-la, a descrevemos e identificamos como uma ação de certo tipo - um "desempenho", isto é, uma ação que só pode ser identificada como apropriada, afortunada ou exitosa (LOUCH, 1966, p. 233). Esses são, certamente, julgamentos de valor, mas são também descritivos. Além do mais, em certos casos dotados de moralidade, uma descrição neutra dos eventos não é apenas imoral, 
mas descritivamente inadequada. Consideremos o célebre exemplo de Isaiah Berlin (citado por BHASKAR, 1979, p. 75) e comparemos os seguintes relatos do que ocorreu na Alemanha nazista: milhares morreram nos campos de concentração nazistas e milhares foram sistematicamente exterminados nos campos de concentração nazistas. Embora ambas as afirmações sejam verdadeiras, a última e mais avaliativa delas é também a melhor e mais adequada. O problema com a posição de Weber, de excluir o valor moral, é que ela não permite que se dê o devido nome aos fatos e às coisas.

A doutrina da neutralidade axiológica não pressupõe apenas expulsar a ciência dos valores, mas também, para citar Andrew Sayer (2011, p. 30) uma vez mais, a expulsar os valores da razão. Para Weber, os valores são meramente subjetivos e arbitrários; não podem ser defendidos de modo objetivo e imparcial. Uma pessoa pode impor os próprios valores pelo uso da força, de ardis ou da persuasão, mas não por meio da razão prática, da argumentação racional, da referência às leis naturais, sentimentos morais, senso de justiça ou uma mistura desses. Com a morte de Deus, todos os sistemas morais do passado (teológico, teleológico, deontológico, consequencialista etc.) também foram crucificados. Para nosso austero cientista, valores são como cores ou sabores. Pode-se gostar deles ou não, mas não se pode argumentar que verde é melhor do que azul (como penso ser) ou arroz melhor do que feijão (na verdade, combinados é melhor). Pode-se racionalmente argumentar sobre meios, mas nunca sobre fins. Fins - assim como Deuses, Demônios e times de futebol - têm de ser escolhidos.

Não há necessidade aqui de recontar as célebres e patéticas declarações de Weber sobre o "politeísmo de valores" e as "eternas disputas entre os Deuses". Supõe-se que todo sociólogo do presente conheça as importantes citações de "Ciência como Vocação" (WEBER, 1988c) ou o artigo sobre objetividade (WEBER, 1988a) e, se tiver algum conhecimento 
sobre filosofia, não terá dificuldade em vincular o posicionamento heróiCo, bravo e solitário de Weber sobre os valores à "Genealogia da Moral" de Nietzsche e seu apelo irreverente ao Super-homem em "Zaratustra".

Para Weber, qualquer apelo à razão prática, justificação moral e fundamento normativo é suspeito. A luta entre deuses não pode ser moderada pelo Homem. As ideias de que valores podem realmente coexistir; o relativismo pode ser superado ou moderado; a diversidade de valores e o sistema de valores podem ser acomodados em um marco pluralista e multicultural; de que o choque de valores, assim como o choque de civilizações, não é inevitável; de que, mesmo na modernidade, há alguns princípios básicos (como o pluralismo) universalmente válidos; de que o agonismo e o antagonismo não são as únicas possibilidades; de que devemos buscar unidade em um nível mais alto de abstração; de que a busca por um 'consenso estendido' entre doutrinas abrangentes deveria ser estimulada; a paz, não a luta, deveria ser a palavra final; nenhuma dessas posições é contemplada seriamente por Weber. Se ele chegava ao fim do dia tão torturado e atormentado, é sem dúvida porque prendeu a si mesmo em uma posição radical, extrema e insustentável.

Assim como ele mesmo, seu trabalho está repleto de tensões, antinomias e paradoxos. Um dos paradoxos no trabalho de Weber é que o leitor relembra com exatidão aquelas passagens em que ele assume uma posição explícita e afirma seus valores. Sem seus julgamentos morais, seu trabalho seria, com certeza, mais tedioso - tão tedioso e aborrecido, talvez, quanto algumas de suas passagens enciclopédicas em "Economia e Sociedade". Outro paradoxo, mais complicado, é que Weber não adota o que ele mesmo diz. Ele advoga por uma ciência neutra, mas no fundo ele é contra essa. Uma ciência sombria, burocrática, só contribuiria para a "petrificação do espírito" - deplora ele - e para colocar uma barra a mais na jaula de ferro. Se ele faz profecias, é porque deseja que sejam refuta- 
das. As profecias antiproféticas com que ele refuta a si mesmo são parte de uma "heurística do medo". O último paradoxo é que, ao argumentar contra o entrelaçamento de fatos e valores, o próprio Weber comete a "falácia naturalista" e recai em mais uma contradição performativa ${ }^{16}$. Contra a "lei de Hume", segundo a qual não se pode derivar o dever ser do ser, valores de fatos, imperativos de descrições, a utilização da falácia naturalista que ele toma como premissa de um argumento incorre ela própria nessa falácia Em lugar de enredar-se constantemente nas teias das inconsistências das dualidades teoria/prática, teoria/teoria e prática/ prática, não seria melhor "engavetar" a neutralidade axiológica? Certamente, não para transformar a sociologia moral em facciosismo político, mas para desenvolver uma sociologia moral melhor, mais consistente e menos atormentada. Fazer uma melhor sociologia moral não a desconectando arbitrariamente de suas origens na filosofia prática e moral, mas, ao contrário, reconectando-a a essa.

\section{Filosofia Prática}

Em "La sociologie comme philosophie politique et réciproquement", que inspirou o título desse meu artigo, Philip Chanial (2011) apela ao desenvolvimento de uma teoria social geral que pudesse "retotalizar" e "renormatizar" as ciências sociais"17. Para contrapor a fragmentação e

\footnotetext{
${ }^{16}$ Uma contradição é performativa quando ocorre não entre enunciados, mas entre um enunciado e o enunciador. Exemplos típicos são: "Eu estava no barco, o barco afundou, ninguém sobreviveu". Também: "Eu afirmo de modo axiologicamente neutro, que se deve ser axiologicamente neutro".

${ }^{17}$ Com "Social Theory as Practice", Charles Taylor (1981, republicado em 1985, II:, p. 91-115) pode ter iniciado uma tendência, mas com nada menos do que três títulos, Bellah é o campeão das variações sobre o mesmo tema. Ver "Sociology as Moral Inquiry" (HAAN et al., 1983), "Sociology as Practical Reason" (1983), "Sociology as Public Philosophy" (BELLAH, et al., 1985).
} 
balcanização das ciências sociais em uma miríade de disciplinas especializadas, ele advoga uma nova síntese da sociologia com a filosofia política e moral ${ }^{18}$. Convergindo com Marcel Mauss e em cooperação com Alain Caillé, com quem edita a "Revue du MAUSS", ele lança uma forte crítica ao utilitarismo em suas distintas variantes (da economia política clássica à escolha racional contemporânea $)^{19}$. Como uma alternativa paradigmática à hegemonia das abordagens economicistas nas ciências sociais, ele propõe uma antropologia maussiana da dádiva, recodificando-a como uma sociologia política de associações e ampliando-a com empréstimos significativos da filosofia política e moral contemporânea (Dewey, Habermas, Honneth, Ricoeur entre outros). O resultado é uma antropologia normativa que portaria os adornos da ciência (CAILLÉ, apud CHANIAL, 2011, p. 12). Essa busca

\begin{abstract}
resgatar os dois imperativos categóricos da investigação sociológica dos Clássicos: compreender, contra toda forma de reducionismo, o Homem em sua unidade; interrogar os fins que coletivamente queremos atribuir à vida social e, assim, julgar as formas socio-históricas de relações inter-humanas e tipos de humanidade - Menschentum, como diria Weber (id., p. 13).
\end{abstract}

Subscrevo sem reservas esse projeto de uma antropologia normativa e sociologia política, mas, para fundamentá-lo adequadamente, penso que precisamos não só repensar a sociologia como uma filosofia moral (e vice versa), mas também como uma filosofia prática (e vice versa). As duas

\footnotetext{
${ }^{18}$ Para um esforço convergente que também inclui os 'Studies' em uma nova síntese, ver Caillé e Vandenberghe, (no prelo).

${ }^{19} \mathrm{O}$ MAUSS, um engenhoso acrônimo para Mouvement Anti-Utilitariste dans les Sciences Sociales/Movimento Antiutilitarista nas Ciências Sociais, reúne antropólogos, sociólogos, cientistas políticos, filósofos e economistas heterodoxos que partilham o interesse sobre a dádiva, inspiram-se n texto seminal de Mauss e publicam a "Revue du MAUSS". Alain Caillé, o fundador do MAUSS, é também o principal teórico do paradigma da dádiva. Declarações programáticas e sintéticas podem ser encontradas em Caillé $(2005 ; 2009)$ e em livro a ser publicado em breve.
} 
estão relacionadas, mas, na medida em que a filosofia moral pressupõe um ator que delibera e avalia, a filosofia prática vem primeiro. Por filosofia prática, refiro-me a toda gama de disciplinas normativas (especialmente ética filosófica, política e direito, mas também psicologia, economia, antropologia e sociologia), as quais deliberadamente dão seguimento às tradições aristotélica, kantiana e hegeliana de filosofia moral e investigam como a validade das normas de ação humana (O que devemos fazer?) e a determinação dos fins (Como devemos viver?) podem ser racionalmente fundamentadas e encontrar evidência social em princípios, normas e valores coletivamente compartilhados.

Se definirmos filosofia prática, em termos gerais, como a totalidade das disciplinas humanas que investigam práticas - com Aristóteles, como ações teleologicamente orientadas envolvendo a determinação racional simultânea dos meios e dos fins (phronesis); com Kant, como ações deontologicamente motivadas que obedecem máximas que satisfazem as condições de objetividade, universalidade e liberdade (praktischeVernunft); e, com Hegel, como princípios axiológicos atualizados em instituições e práticas sociais (Sittlichkeit) -, podemos incluir economia, sociologia e antropologia nessa instância e compreender as ciências sociais como razão prática $(B E L L A H, 1982)^{20}$. Como a filosofia prática não é nem teoria (theoria) nem arte (techne), mas conhecimento prático (praxis) - isto é, conhecimento diretamente implicado na determinação e execução racionais de um curso de ação em uma situação de incerteza e num contexto de justificação -,

\footnotetext{
${ }^{20}$ Para uma boa investigação da ética neoaristotélica, neokantiana e pós-hegeliana, ver Honneth (2000, p. 171-192). Para aqueles que poderiam questionar a possível inclusão da economia na filosofia prática, permitam-me relembrar que, até o lluminismo Escocês, a economia era parte, embora pequena, da ética e da política. O vínculo histórico com Aristóteles explica porque alguns de seus conceitos mais fundamentais, começando pelo próprio nome da disciplina, mas também "bens" (!), referem-se à organização racional o domicílio (oikos) no contexto da busca pela "vida feliz" de seu chefe, como precondição à participação na esfera pública. O que vale para a economia vale também a fortiori para a antropologia e a sociologia.
} 
toda teoria da sociedade fundada em uma concepção de ação social que não exclui a determinação dos fins e não reduz a ação a uma dimensão instrumental ou estratégica pode ser considerada uma formalização do conhecimento comum e, portanto, uma forma de sociologia prática ${ }^{21}$.

O vínculo interno entre conhecimento prático e execução de ação, o qual caracteriza o objeto das disciplinas praxiológicas, pressupõe que a ação tenha as seguintes características: reflexividade, intencionalidade, normatividade e humanidade. A reflexividade ou a capacidade do sujeito de pensar-se como um objeto (conversações internas); intencionalidade, ou a implicação teleológica da reflexão enquanto um momento na constituição do ato como um ato de um certo tipo; normatividade ou a justificação do ato por meio da referência a discursos avaliativos ("julgamentos") que o motivam ("motivos") e direcionam ("fins"); e humanidade ou a relação vital (a Wirkunszusammenhang de Dilthey) entre a parte e o todo, que conecta o indivíduo à comunidade mais ampla (idealmente, e de forma contraditória, à comunidade mais ampla que é idêntica ao "universo de discurso") da qual aquele é parte. Juntas, essas quatro referências envolvidas na constituição das ações sociais como ações morais conferem às práticas uma qualidade dinâmica.

Graças ao conhecimento prático e à razão prática, a conexão entre ação social, ordem e mudança assegura que a dialética entre agência e estrutura, liberdade e restrição jamais se suspenda. A razão prática, diz

\footnotetext{
${ }^{21}$ No prefácio dos Fundamentos da Metafísica dos Costumes, Kant (1983, p. VI-VIII) faz uma distinção clara entre uma parte racional e outra empírica da ética. Ele denomina a parte racional como "filosofia moral" e a parte empírica como "antropologia prática", e afirma que, para desenvolver uma filosofia moral como pura metafísica da moral, a primeira precisa ser totalmente purificada de qualquer referência à empírica. Tudo o que proponho neste artigo é justamente o oposto: para desenvolver uma sociologia e uma antropologia morais como uma filosofia prática, é preciso superar a separação entre filosofia e ciência, entre o transcendental e o empírico, entre o normativo e o descritivo.
} 
Ricoeur (1986, p. 285), é o conjunto das medidas adotadas por indivíduos e instituições para preservar e restaurar a dialética mútua entre liberdade e instituições sem as quais não há ação significativa. Para enfatizar o impacto dinâmico do conhecimento prático, posso agora concluir e redefinir filosofia prática como a totalidade das disciplinas que investigam tudo que possa ser mudado por meio de ações e práticas transformativas; e sociologia prática como a investigação e aplicação humanista das ações sociais reflexivas, intencionais e normativas que visam transformar o eu, a cultura e a sociedade ${ }^{22}$.

De acordo com essa perspectiva morfogênica sobre a transformação do eu, da cultura e da sociedade em geral (VANDENBERGHE, 2014, p. 67-84), podemos agora levantar uma questão antropológica essencial e fundamentar a antropologia normativa de Chanial em algumas capacidades humanas distintivas: Que tipo de animais são seres humanos? Como podemos descrever suas características peculiares de modo a melhorar, ou pelo menos, expandir nossa compreensão sobre a ação social e as instituições humanas? (SMITH, 2003, p. 3).

A questão da natureza humana é, sem dúvida, difícil - como Charles Taylor (1988, p. vii) perspicazmente observou, ela é tremendamente necessária e insuportavelmente problemática. Para evitar as armadilhas do essencialismo (especismo, antropocentrismo, logocentrismo etc.), proponho definir o ser humano como um ser que é, por natureza, cultural, dotado de uma capacidade inerente para a contínua autotransformação.

\footnotetext{
${ }^{22}$ A Humanística, na forma como é desenvolvida, ensinada e praticada na Universidade Holandesa de Estudos Humanistas, é uma ciência humana aplicada, normativa e empírica que se insere na tradição humanista progressista pós-secular. Decididamente interdisciplinar (ciências sociais e humanidades), ela se propõe estudar o ser humano a partir de uma dupla perspectiva, ao mesmo tempo existencial (lida com o processo humano de atribuição de sentido) e social (visa contribuir para a humanização do mundo). Para mais informação, acesse www.uvh.nl e visite a instituição em Utrecht.
} 
Conforme a definição clássica de Aristóteles, do ser humano como um ser dotado da fala e capacidade de raciocínio (zoon echon logon, traduzido pelos romanos como animal rationale), eu gostaria de destacar as capacidades constitutivas e transformativas das cultura, linguagem e prática, e sugerir que, juntas, elas formam a tríade ontológica do Espírito (Geist), a qual distingue o universo natural do universo humano. Ao destacar as capacidades constitutivas do Espírito, não pretendo negar que o mundo natural seja um mundo humano e que o mundo humano seja também um mundo natural ${ }^{23}$. Ao contrário, minha proposição é que, se quisermos compreender o que torna humano o universo humano e, por implicação, faz humanas as ciências humanas, não podemos ignorar as múltiplas inter e intrarrelações ente cultura, linguagem e práticas que constituem os seres humanos, os quais, como sujeitos práticos - graças à mediação da cultura e da linguagem e graças às práticas simbólicas -. transformam continuamente o eu, a cultura e a sociedade que os tornam humanos.

Se me permito essa digressão elementar, é porque quero conceber as ciências sociais como ciências humanas, e as ciências humanas como ciências morais. Geisteswissenschaften - literalmente ciências do Espírito - é a tradução para o alemão, feita em 1847 por Schiel, das ciências da moral de John Stuart Mill24. A "Lógica das Ciências Morais" de Mill tornou-se Logik der Geisteswissenschaften. Ao transitar da Inglaterra (Mill), via Paris (Comte), para Berlin (Dilthey), o termo perdeu todos os

\footnotetext{
${ }^{23}$ Sobre isso, ver Morin (2008).

${ }^{24} \mathrm{Hoje}$, o termo ainda é muito utilizado na Alemanha (pelo DAAD, por exemplo) como um termo genérico que reagrupa cerca de 40 distintas disciplinas, abarcando desde teologia, filosofia e artes via psicologia e história, até antropologia e sociologia, sob um único departamento. Em inglês, o termo não é retraduzido como moral sciences, mas como humanities (humanidades). Enquanto esse termo logra capturar o vínculo essencial com Bildung e Bildungshumanismus das artes liberais, as sciences de l'homme francesas são mais promissoras para o desenvolvimento de uma teoria social geral como antropologia normativa com um propósito prático e moral.
} 
atributos naturalista, positivista, empirista, utilitarista e individualista a ele atribuídos pelo jovem Mill. Em mãos dos alemães, que revitalizaram as ciências humanas injetando nelas uma boa dose de idealismo especulativo, as Geisteswissenschaften cada vez mais passaram a ser associadas a atributos opostos: humanismo, historicismo, idealismo, hermenêutica e holismo são peculiares às ciências moral, histórica e cultural germânicas. Embora o conceito de Geist tenha a vantagem de manter sua associação com uma compreensão socio-histórica da cultura - entendida, em sentido amplo, como a totalidade das objetivações da vivência humana (a Erlebnis de Dilthey) numa esfera transpessoal de significados, valorações e expressões comuns -, ele também porta o risco de contaminar-se com uma filosofia idealista especulativa da história, que tem seu ápice na "Fenomenologia do Espírito" de Hegel. Para afastar o risco e despojar as Geisteswissenschaften de seu pesado lastro metafísico, é preciso eliminar completamente a macroteleologia hegeliana e marxista da história e se limitar às microteleologias das múltiplas histórias de ação social transformativa.

Através dessa autolimitação, as Geisteswissenschaften renunciam ao evangelho do Espírito Absoluto e reintegram-se ao movimento neokantiano da Kulturwissenschaften de Dilthey, Simmel, Weber e, mais próximos de nós, Cassirer, Gadamer, Ricoeur e Habermas. A perspectiva das ciências sociais como ciências culturais, morais e práticas, que se seguiu ao colapso do idealismo absoluto (1831-1933) e do materialismo histórico (1842-1989), é aquela do neokantismo pós-hegeliano, para tomar de empréstimo a categoria contraditória, mas brilhante de Paul Ricoeur (1986, p. 279 e 305) ${ }^{25}$.

\footnotetext{
${ }^{25}$ Configurações de ideias e sistemas filosóficos também têm suas biografias: nascem, crescem e entram em coma, o que não impede que voltem à vida ou que tenham uma vida depois da morte, por assim dizer. Le mort saisit le vif. As datas que escolhi para o idealismo absoluto coincidem com o nascimento de Hegel e a tomada do poder por Hitler; para o materialismo histórico, a publicação do texto de Marx sobre a censura no Deutsche Jahrbücher e o colapso do "socialismo real" na Europa Central. A morte da filosofia marxista da história antecede a queda do Muro de Berlim, mas, desde então, pelo menos no hemisfério norte, perdeu toda a credibilidade e definitivamente deixou de ser "o horizonte insuperável de nosso tempo".
} 
Teoria social ainda tributária da tradição das Geistes- und Kulturwissenschaften e que dá continuidade a essas na forma de uma filosofia moral e prática, a sociologia torna-se a ciência do Espírito Objetivo, isto é, da totalidade das expressões vitais, dos entendimentos normativos e dos significados culturais dos seres humanos, que se estendem da linguagem, religião e ciência às atividades políticas, artísticas e econômicas. Essas podem ser entendidas como consolidações de intencionalidades coletivas em formações culturais autônomas. Sendo, ao mesmo tempo, expressões de grupos sociais organizados em uma totalidade cultural autônoma que segue sua própria lógica, as formações do Espírito Objetivo são propriamente sociais e lógicas, portanto, sociológicas (DILTHEY, 1979, p. 135-136).

$\mathrm{Na}$ tradição francesa, encontramos a mesma ideia, mas sob uma diferente denominação. Para Durkheim, Mauss e Fauconnet, a sociologia é a ciência das instituições, de sua gênese e funcionamento (DURKHEIM, 1987, p. xxii). Com Mauss e Fauconnet, mas sem dúvida também com Marx e Weber, podemos entender as instituições como totalidades de atos e ideias instituídas que os indivíduos têm diante de si e que se impõem a eles em maior ou menor grau (MAUSS e FAUCONNET, 1969, p. 17). Enquanto expressão e consolidação de hábitos coletivos (id., 10), elas incorporam o espírito dos coletivos (ibid.) e orientam as práticas, prescrevendo "modos coletivos de pensar, sentir e agir" que são conformes aos valores compartilhados pelo coletivo e seus membros ${ }^{26}$. Na medida em que as instituições são, acima de tudo, constituídas de representações sociais - instituições só existem como representações (id.) - elas não devem ser pensadas como forças inertes, mas sim como formas simbólicas

${ }^{26} \mathrm{Cf}$. "Prolegomena to a Theory of Social Institutions", de Parsons: A função das instituições é sempre a mesma - a regulação da ação de modo a mantê-la em relativa conformidade com os principais valores e atitudes relacionadas a valores compartilhados pela comunidade (PARSONS, 1990, p. 331). 
ativas que representam a sociedade perante seus membros e mediam sua influência formativa sobre eles estruturando as práticas a partir de dentro. Contrapondo-nos a Durkheim, devemos, portanto, insistir em que os indivíduos não confrontam as instituições "a partir de fora"; ao contrário, com Mauss, devemos enfatizar que as instituições vivem nas pessoas e, ademais, só vivem porque existem pessoas que as ativam e animam na atividade da vida cotidiana ${ }^{27}$. As instituições são a conexão viva entre os indivíduos e a sociedade e, como tal, representam o exterior no interior (alteridade próxima). Nesse sentido, pode-se dizer que a sociologia é uma psicologia (id., 26). O vínculo constitutivo entre representações (tanto coletivas como individuais) e práticas (tanto individuais como coletivas) é o que mantém viva a dialética. Subjacentes às representações, existem práticas; no cerne das práticas, existem representações; e subjacentes a ambas estão as próprias experiências de vida.

Para estabelecer uma continuidade entre a sociologia moral, as ciências humano-culturais e a tradição da filosofia prática, farei agora uma "virada praxiológica" para pensar as instituições como conjuntos normativos de práticas sociais habituais e reguladas que produzem (reproduzem e transformam) a sociedade de acordo com princípios, valores e normas sobre os modos de vida coletivamente partilhados ${ }^{28}$. Enquanto conjunto de hábitos coletivos que prescrevem e proíbem práticas sociais como moralmente corretas ou incorretas, boas ou más, justas ou injustas, as ins-

\footnotetext{
${ }^{27}$ Para uma boa investigação sobre as diferenças entre Durkheim e seu sobrinho, ver Caillé (p. 27-44, esp. p. 33-39).

${ }^{28} \mathrm{~A}$ "virada prática" nas ciências contemporâneas está associada, na filosofia, às obras de Heidegger, Wittgenstein e ao pragmatismo norte-americano; na sociologia, a Garfinkel, Giddens e Bourdieu. Para uma discussão bastante perspicaz da ontologia das práticas na teoria social contemporânea, ver Reckwitz (2002). Na virada prática, existe uma virada moral (Taylor, Honneth, Jaeggi, Stahl) e, às vezes, mesmo um retorno à teoria aristotélica da prática e da prudência (Maclntyre, Chris Smith, Flyvbjerg).
} 
tituições não podem existir sem que existam concepções culturais sobre a ordem social ou sem certas autoconcepções que são simultaneamente humanas, culturais e pessoais.

Há sempre um conhecimento pré-teórico sobre o que está ocorrendo entre os membros da sociedade, o qual é formulado nas descrições de si e do outro, envolvidas nas instituições e práticas sociais. Uma sociedade é, entre outras coisas, um conjunto de instituições e práticas, e estas não podem existir e serem perpetuadas sem determinadas autoconcepções (TAYLOR, 1985, II, p. 93).

Concepções culturais da sociedade e do ego estão mutuamente envolvidas nas, e constituídas por, práticas cotidianas que conectam o eu à sociedade e o indivíduo à humanidade como a parte ao todo. Mediadas por representações simbólicas da sociedade, referentes ao que é justo ("justo para todos") e o que é bom ("bom para mim"), as práticas são ao mesmo tempo sociais e individuais, coletivas e pessoais, universais e particulares; além disso, elas se engrenam ao mundo exterior, espiritual e material. Se as concepções normativas do eu e da sociedade têm eficácia causal, é porque elas regulam a partir do interior as ações teleológicas dos indivíduos, representando-os a partir de representações simbólicas exteriores sobre a vida feliz e a sociedade feliz.

\section{A vida feliz com e para outros em instituições justas}

Nesta seção final, pretendo sustentar que nosso horizonte moral contemporâneo é constituído por diversas correntes e segmentos de filosofia moral herdadas do passado, embora também proponha roteiros de vidas possíveis no futuro que ainda operam no presente. É como se, a cada vez, uma corrente se somasse à que a precede, progredindo na direção de uma crescente diferenciação e síntese (DILTHEY, 1979, p. 169). Para construir 
meu argumento, trarei um panorama muito breve da história da filosofia moral na tradição ocidental (por falta de competência, devo renunciar a qualquer discussão sobre filosofias morais não ocidentais). Como estou buscando material que me ajude a renovar uma antropologia positiva na tradição antiutilitarista, esse panorama será necessariamente seletivo, para não dizer, parcial ${ }^{29}$. De qualquer modo, argumentarei que nossas atuais instituições morais consistem de uma mistura de concepções teleológicas clássicas da eudemonia (a "vida feliz"), da ética judaico-cristã do amor, cuidado e solicitude ("com e para com outros") e de concepções deontológicas modernas de justiça ("em instituições justas"). Bebendo, uma vez mais, do incrível talento de Paul Ricoeur para sintetizar temas complexos em uma frase mnemônica, vou caracterizar nosso horizonte moral em termos de uma visée da vida feliz com e para outros em instituições justas (RICOEUR, 1990, p. 199-236) ${ }^{30}$. Para desdobrar esta frase e mostrar aquilo que Weber deliberadamente eliminou de seu escopo, examinarei a ética eudemônica de Arsitóteles (phronesis), a concepção de amor de Agostinho (agape) e a concepção secular de benevolência (sympathy) do lluminismo Escocês, o imperativo categórico de Kant e o sistema de moral de Hegel (Sittlichkeit).

\footnotetext{
${ }^{29} \mathrm{Na}$ verdade, deixarei de lado sistematicamente a tradição consequencialista. Para um panorama mais abrangente da filosofia moral e política de uma perspectiva antiutilitarista, ver Caillé, Lazzeri e Sennelart (2001).

${ }^{30} \mathrm{Na}$ trilogia de Honneth (2000, p. 133-170), encontra-se uma reconstrução similar da filosofia moral contemporânea: 1) correntes neo-aristotélicas e neo-hegelianas de comunitarismo (Maclntyre, Walzer, Honneth); 2) liberalismo neokantiano (Habermas, Rawls) e 3) ética pós-moderna do cuidado (Lyotard, Derrida, Levinas). A propósito, noto que lema de Ricoeur omite a visée de um ambiente sustentável, que é hoje cada vez mais reconhecido com preocupação, por parcelas crescentes da população, como uma precondição para a sobrevivência humana e, portanto, também para a vida feliz na e com a natureza, em uma forma de vida ecologicamente sustentável.
} 
"A vida feliz": A ideia de que as ciências sociais continuam a tradição da filosofia prática e moral como uma antropologia e sociologia normativas pode ser discutível, mas, como oportunamente nos lembra Bellah, há não muito tempo, a maior parte do que hoje chamamos de ciências sociais era ensinada, quando de fato o era, sob a denominação de filosofia moral (BELLAH et al., 1985, p. 299). Isso foi possível porque, até Nietzsche e Weber declararem fins e valores como tabus, pensava-se que a ciência social não só submete os meios, mas também os fins, a uma reflexão racional. Embora já não seja usual tratar Platão e Aristóteles como sociólogos primevos, vale um retorno aos antigos, não por mera erudição, mas como prolegômeno filosófico à sociologia moral.

A "Ética a Nicômaco" de Aristóteles é, na verdade, uma teoria da ação que articula reflexivamente práticas a um projeto de vida que é regulado por uma natureza moral (hexis) e uma sabedoria prática (phronesis) e busca a realização de uma vida virtuosa, boa e feliz: ser feliz fazendo o bem. O conhecimento prático intervém nesse projeto de vida não como uma episteme (ciência ou conhecimento teórico), nem como techne (arte ou saber técnico), mas precisamente como uma deliberação racional sobre a relação entre fins e meios que direciona as práticas para seu objetivo final: felicidade ou eudemonia.

Para Aristóteles, a felicidade não é transitória, mas permanente; não é um estado, mas uma prática que implica uma fusão de virtude moral (hexis) e virtude intelectual (phronesis) como modo de vida - Mas devemos acrescentar: em uma vida inteira, pois uma andorinha só não faz um verão... (1098a, p. 10-15). As virtudes, como coragem, moderação, generosidade e justiça, não são dadas por natureza, mas adquiridas pelo exercício e formação. É fazendo a coisa certa, pelo motivo certo, do modo certo, sem excesso e sem déficit, que uma pessoa se torna virtuosa, que a virtude se torna uma disposição arraigada e se consolida na forma de 
Sociologias, Porto Alegre, ano 17, no 39, mai/ago 2015, p. 60-109

caráter. A excelência moral como caráter é resultado de práticas virtuosas - porque somos, de algum modo, parcialmente responsáveis por nosso caráter (1114b, p. 20-25) - mas também é uma condição, porque nos tornamos virtuosos pelo hábito. É cultivando as virtudes morais na prática, fazendo o bem, e agindo bem, continuamente, e também exercitando a virtude intelectual da prudência e deliberando de forma correta sobre os fins e meios de ação corretos a bem de ser boa que, por fim, depois de tudo, a pessoa será boa e virtuosa e, portanto, feliz.

Ao contrário dos antigos, nós modernos já não acreditamos na existência de uma ordem cósmica que sustente nossa busca por uma vida bela e feliz. Inevitavelmente, tornamo-nos pluralistas; por falta de opção, tornamo-nos (quase) pós-metafísicos e renunciamos a doutrinas abrangentes. Já não pensamos haver apenas um único curso de ação correto para conduzir a uma vida feliz. Isso não significa que sejamos niilistas e que todas as escolhas sejam arbitrárias. Significa apenas que não podemos impor nossa concepção particular de vida feliz e de sociedade feliz a todos, sem recair em paternalismo ou autoritarismo. A emergência do neoaristotelismo e o debate relacionado a virtudes, benevolência e excelência interiores nos escritos de Arendt, Gadamer, Maclntyre, Spaemann e Nussbaum revelam, contudo, que a ideia de prosperidade humana não perdeu seu apelo. O que resta da phronesis em tempos pós-metafísicos e em sociedades pluralistas com visões de mundo concorrentes é uma concepção narrativa e normativa da identidade como uma busca infindável por autenticidade (FERRARA, 1994).

"Com e para os outros": para Aristóteles, a vida feliz não é uma vida solitária, porque, sem amigos, ninguém escolheria viver (1155a, p. 5-10). O homem é de fato um animal político e a amizade (philia) é também uma virtude. Graças à presença do outro, a subjetividade torna-se intersubjetividade e a questão da identidade se abre para a diferença e a alte-

http://dx.doi.org/10.1590/15174522-017003903 
ridade. Para Agostinho, o outro se torna o Outro. Aqueles que buscam a felicidade nesta vida e em si mesmos não a encontrarão. Amor e vida são sistematicamente depreciados. O que conta é a fé. O verdadeiro crente é apenas um peregrino em jornada terrena rumo à vida eterna na Cidade de Deus. O fim último ou bem supremo dessa cidade é a paz na vida eterna, ou a vida eterna em paz (AGOSTINHO, 1971b, p. XIX, 11). A vida humana é um teste. A paz que encontramos aqui é apenas um consolo para nossa miséria (id., XIX, 27).O único verdadeiro amor é o amor de Deus, para Deus e em Deus. O amor que sentimos por nosso próximo é, no melhor dos casos, o amor do divino e do eterno no Homem, que Ele criou; no pior dos casos, é concupiscência e pecado.

Ao contrário de seus antigos antecessores, que valorizavam philia e eros, Agostinho só ama e valoriza o que Deus ama. Embora os estudiosos da Bíblia e do Torá, sem dúvida, poderão apresentar autênticas justificações e descrições do amor ao próximo (caritas, agape) na teologia judaico-cristã, tenho a impressão de que o elemento fraternal estará quase sempre consagrado e aninhado no elemento paternal que comanda a ascensão da alma e também a abertura para o outro ${ }^{31}$. Contudo, o que se obtém com a tradição religiosa, e especialmente com Agostinho, é a ênfase na introspecção e na intimidade, reflexão e mediação. Em suas Confissões, um poema de amor em prosa dirigido a Deus, o giro para dentro de si conduz à ascensão. Sois mais profundo que o que tenho de mais íntimo e mais sublime do que o de mais elevado existe em mim. [...]

\footnotetext{
${ }^{31}$ Mesmo havendo algo divino no amor, quero pensar o amor como "amor puro", como o amor entre duas pessoas não mediado pela Terceira Pessoa. Embora eu esteja convencido de que a fenomenologia pós-husserliana ofereça o melhor registro descritivo para a questão, a maior parte das análises que conheço de sentimentos dirigidos a outros (amor, compaixão, solicitude, etc.) na fenomenologia contemporânea tem conotações teológicas. Isso não vale apenas para fenomenólogos de tradição cristã (Scheler, Ricoeur, Marion, Henry), mas também, e ainda mais, para os de tradição judaica (Buber, Levinas, Derrida, Benny Lévy).
} 
O que reside na essência é superior (AGOSTINHO, 1971a, III.vii.11 e X.vi 9). Para o Bispo de Hipona, a conversa interior não é uma conversa com outros. Não é comunicação, mas comunhão. De modo similar, não é uma conversa, mas uma conversa em Deus.

Para encontrar investigações sobre a intersubjetividade que ampliem as abordagens clássicas da amizade de Aristóteles, Cícero e dos Estóicos e que não sejam mediadas pelo Outro, focarei agora no lluminismo Escocês - aliás, uma das mais menosprezadas tradições ancestrais da sociologia - e à sua análise da benevolência. Na protossociologia de Hutcheson e Ferguson, e principalmente em Hume e Adam Smith, podem-se encontrar explanações sistemáticas da sociabilidade humana e ricas investigações empíricas sobre a sociedade civil, que colocam em primeiro plano o papel dos sentimentos morais como simpatia, compaixão, cuidado, tato e outros sentimentos ternos, captando nossas percepções sobre o significado de ser com e para os outros. Em "Teoria dos Sentimentos Morais", Adam Smith desenvolve uma teoria da sociedade que não está fundada na ação nem na paixão, mas na observação de si mesmo e dos outros. Sua ideia fundamental, que influenciou Charles Horton Cooley, Georg Herbert Mead e da qual se podem também encontrar ecos na Teoria da Justiça de John Rawls, é que uma ação se torna moral quando os atores descentralizam seu olhar, de modo a olhar, ver e julgar a si mesmos através do olhar dos outros. O desejo de amar, de ser amado, de agradar e tornar-se aceito instiga o sujeito a tornar-se ele mesmo, graças ao outro. A abertura para o outro em pensamento, mas também em ação, é o traço distintivo da solidariedade. Ao julgar a si mesmo como gostaria de ser julgado por outros, portanto, através do atalho de um outro benevolente (o chamado "observador imparcial") o indivíduo torna-se moral e virtuoso: Nenhuma ação que não esteja acompanhada de um sentimento de autoaprovação pode ser propriamente chamada de virtuosa (SMITH, 1976, III, 
p. 6-13). Graças ao mecanismo de descentramento sentimental, pode-se entender melhor o que motiva os atores a sair de si mesmos para cuidar de outros ou comunicar-se com outros.

Pode parecer surpreendente ver uma das bases do antiutilitarismo em Adam Smith, o fundador da economia clássica. Mas a ideia de que o autointeresse e o mercado pressupõem o interesse por outros é algo próprio de uma sociedade civil em que homens e mulheres se encontram para falar e comunicarem-se constitui uma das noções centrais não só do lluminismo Escocês, mas também das tradições francesa e alemã da sociologia. Entendida como uma ciência moral, a sociologia investiga as precondições morais do mercado e das trocas - a base pré-contratual do contrato, como afirma Durkheim (1986, p. 177-209) em um dos textos fundadores da sociologia - e desenvolve a ideia de que a interdependência humana e os laços morais da sociedade civil sustentam o mercado e o estado. Subjacente à sociedade (Gesellschaft), está a comunidade (Gemeinschaft). Subjacente às trocas, temos a dádiva. Subjacente ao egoísmo e ao poder, existe a reciprocidade e a generosidade. Com a moral da reciprocidade, estamos tocando uma das pedras fundamentais sobre as quais as sociedades humanas se constroem (MAUSS, 1989, p. 148). A vida social entre cidadãos anônimos só é possível porque vínculos morais unem os membros da sociedade uns aos outros em uma comunidade de solidariedade. Contrapondo-nos a Hobbes, mas alinhados ao Iluminismo Escocês, podemos, então, pensar a moralidade como sendo constitutiva da comunidade e constituir a sociologia como uma filosofia moral antiutilitarista que fundamenta o bem comum na benevolência, na reciprocidade e na sociabilidade.

"Em instituições justas": a visée moral de conduzir uma vida feliz com e para outros não pode ficar limitada à pequena comunidade de concidadãos, mas, a partir do eu constituído através de outros, precisa 
expandir seu alcance e tender à universalidade. Graças ao encontro com outros que são parte de uma comunidade de reciprocidade e solidariedade, a ética teleológica da autenticidade e da autorrealização com e para os outros encontra sua extensão lógica numa ética deontológica de autonomia e autodeterminação. Através da inclusão do outro anônimo - o "cidadão sem rosto" - os laços fraternos da comunidade se distendem, mas também se estendem em uma sociedade que assegura, pelo menos em princípio, liberdade e igualdade e, portanto, justiça para todos. Assim, seguindo o arco intencional da moralidade, que conecta os projetos de vida do indivíduo com a vida da comunidade e não só, chegamos à ideia de uma sociedade bem ordenada, com instituições justas, sem exclusão social.

$\mathrm{Na}$ filosofia moral de Kant, encontra-se a formulação mais rigorosa da perspectiva deontológica ou imperativa do justo, que caracteriza a moral moderna. Para Kant, a moral nada tem a ver com a busca da felicidade, e tampouco com utilidade ou sentimentos morais. Mas tem tudo a ver com a subordinação da vontade a uma lei universalmente válida. Age-se moralmente, quando se age por dever, tanto em relação a si mesmo como em relação aos outros, e em respeito à lei (aus Achtung fürs Gesetz - Kant, 1983, p. 14). O critério de universalidade de Kant é formal e procedimental. Não diz o que um ator deve fazer, mas exige que ele ou ela sigam máximas (isto é, regras subjetivas de ação) que não são subjetivas, mas objetivas, não empíricas, mas a priori, as quais devem ser respeitados sempre e sem exceção. A primeira formulação do imperativo categórico: age conforme uma máxima que possa valer, ao mesmo tempo, como uma lei universal (p.52) indica claramente que uma ação só é moral quando sua justificação passar no teste da universalidade. Enquanto a primeira formulação caracteriza o princípio da moralidade, a segunda e a terceira determinam, respectivamente, seu fim e sua destinação. A segunda formulação: age de tal maneira que possas usar a humanidade, tanto em tua 
pessoa como na pessoa de qualquer outro, sempre e simultaneamente como fim e nunca simplesmente como meio (p. 67) deriva da primeira e vincula a universalidade à humanidade do outro e à dignidade de cada um e de toda a pessoa. Mudando a perspectiva, de um ator que segue a lei para um que legisla para todos os possíveis seres racionais, a terceira formulação: Todo ser racional deve agir como se através de sua máxima fosse sempre um legislador no reino universal dos fins (p. 76) relaciona a universalidade à autonomia e ao ideal de autodeterminação. Juntas, as três formulações do imperativo categórico introduzem com força o princípio (universalidade), o fim (humanidade) e o ideal (autonomia) da moral, em um discurso normativo da modernidade.

Em sua crítica a Kant, Hegel argumentou que a moral kantiana pressupõe instituições sociais que incorporam a ideia de universalidade e atores sociais que a colocam em prática e, assim, a realizam. Com uma moral objetiva (Sittlichkeit) que é institucionalizada e praticada, a moral subjetiva (Moralität) fica impotente, abstrata e não-substantiva. Sem o espírito, [a] forma que o direito assume no dever e na lei aparece-lhe como letra morta e fria, como uma prisão (HEGEL, 1970, p. 19). Mesmo que os indivíduos sejam, em teoria, reconhecidos como autores da lei, eles não se reconhecem como tal. Mesmo que a liberdade seja formalmente reconhecida como um princípio, ela não é vivenciada e experimentada como tal. Sem o respaldo de instituições como a família, a sociedade civil e o estado que deem sustentação para as regras morais e as transformem em práticas vivenciadas, sem costumes concretos que confirmem nas práticas os princípios prescritos pela razão, a moral fica suspensa no ar. É só quando a moral se torna habitual e prática que ela se torna real. Trezentos anos depois da filosofia prática de Kant e da filosofia dos direitos de Hegel, os princípios modernos de universalidade, humanidade e autonomia conseguiram realizar-se e institucionalizar-se em defesa dos direitos huma- 
nos. O que foi apenas uma Declaração, em 1789 (Déclaration des droits de I'homme et du citoyen), tornou-se hoje uma realidade concreta - ao ponto de, quando seus direitos são violados e os seres humanos não são reconhecidos como seres humanos e como cidadãos, saem às ruas para protestar e exigir seus direitos.

Agora que já discutimos como as dimensões individual, interpessoal e societal da moral estão institucionalizadas na civilização ocidental, podemos entender melhor o horizonte normativo que informa as práticas sociais transformadoras do presente. Conformado por múltiplas correntes e estratos do passado, o horizonte moderno e pós-moderno abarca toda a distância que separa a antiga maxima moralia da perfeição humana da atual minima moralia dos direitos humanos. Com seu desejo de autenticidade, seus sentimentos de benevolência e seus discursos de direitos humanos, os atores contemporâneos aspiram ser, ao mesmo tempo, plenamente humanos, compassivamente humanos e idiossincraticamente pessoais. Da perspectiva sociológica, tais aspirações para transformar a si mesmos, a comunidade à qual se pertence, e o mundo como um todo, podem ser recodificadas como scripts normativos e lidas como práticas pessoais. Reciprocamente, pode-se também entender a sociologia como um script e uma prática que buscam elucidar quem somos, enquanto atores, o que somos como sociedade e aonde queremos chegar como humanidade.

\section{Conclusão}

Os pressupostos filosóficos que organizam a sociologia normativa como filosofia prática e moral são o resultado de uma cruzada secular para investigar os princípios, normas e valores que respaldam a constituição da sociedade. Como uma resposta prolongada a toda a tradição utilitarista-atomística-individualista, que sistematicamente reduz a impor- 
tância do papel constitutivo desempenhado pela cultura de um modo geral e pela moral em particular na estruturação da sociedade, a tradição sociológica deu continuidade, por seus próprios meios, à pesquisa empírica teoricamente informada sobre as práticas, a busca por uma sociedade boa, justa, e ordenada de indivíduos em interação e inter-relação que atuam de forma concertada para produzir, reproduzir ou transformar a ordem social de que fazem parte.

De Comte a Mauss e Boltanski, de Marx a Habermas e Honneth, de Hume a Mead e Parsons, as principais tradições de teoria social geral buscaram recuperar os fundamentos morais da ação social, da ordem e da mudança. Mediante um diálogo explícito com Kant, Hegel, Marx e, muitas vezes, também com Nietzsche; a partir de uma fusão criativa entre teoria social e filosofia moral, aqueles autores buscaram recuperar partes da tradição aristotélica da filosofia prática que Hobbes, Bentham e Mill haviam rejeitado.

Entretanto, como mostrou Donald Levine (1995) em sua reconstrução dialógica das tradições nacionais da sociologia, a maior parte dos pressupostos que informavam a filosofia aristotélica foram recuperados um a um na teoria social pós-hobbesiana. Agora que a sociologia moral está no auge, talvez tenha chegado a hora de avaliar nossa herança e reformular a teoria social como uma prática e um modo de vida. Já é tempo de abandonar falsas interpretações de nossas práticas científicas. Como se pudéssemos apagar os fundamentos sobre os quais nos apoiamos. Ao tomarmos consciência das tradições que nos alicerçam e a que damos continuidade, quem sabe poderemos também transformá-las e às nossas autoconcepções. Ao repensar a teoria social como uma prática coletiva, estaremos devolvendo-a ao lugar de onde vem: a sociedade, mas agora entendendo-a como um projeto de humanização progressiva de suas instituições e suas práticas. 
Sociologias, Porto Alegre, ano 17, no 39, mai/ago 2015, p. 60-109

Frédéric Vandenberghe - Ensinou em várias Universidades estrangeiras (UCLA, Manchester University, European University Institute, Brunel University London, Yale University e Université Catholique de Louvain-la-Neuve) e brasileiras (UNB, UFPE, UFRJ, IUPERJ). Atualmente é professor e pesquisador do Instituto de Estudos Sociais e Politicos (IESP) da UERJ e coordena o Grupo de Pesquisa SOCIOFILO. $>$ frederic@iesp.uerj.br

\section{Referências}

1. ALEXANDER, J.. Introduction: Understanding the Relative Autonomy of Culture. In: ALEXANDER, J.; SEIDMAN, S. (eds.). Culture and Society. Contemporary Debates. Cambridge: Cambridge University Press, 1990. P. 1-30.

2. ALEXANDER, J.; SMITH, P.. The Strong Program in Cultural Sociology: Elements of a Structural Hermeneutic. In: ALEXANDER, J.. The Meanings of Social Life: A Cultural Sociology. New York: Oxford University Press, 2003. P. 11-26.

3. ARENDT, H.. Some Questions of Moral Philosophy (Lecture of 1965). In: Social research, 61, 4, 1994, p.739-764.

4. ARISTOTLE. Éthique à Nicomaque. Traduction J. Tricot. Paris: Vrin, 1979.

5. AUGUSTINE. Confessions. In: Great Books of the Western World. Vol. 18: Augustine. Chicago: Encyclopedia Britannica, 1971a.

6. AUGUSTINE. The City of God. In: Great Books of the Western World. Vol. 18: Augustine. Chicago: Encyclopedia Britannica, 1971b.

7. BARBALET, J.. Emotion, Social Theory and Social Structure. A Macrosociological Approach. Cambridge: Cambridge University Press, 2001.

8. BELLAH, R.. Social Science as Practical Reason. In: CALLAHAN, D.; JENNINGS, B. (eds.). Ethics, the Social Sciences and Policy Analysis. New York: Plenum Press, 1982. P. 37-64.

9. BELLAH, R.. The Ethical Aims of Social Inquiry. In: HAAN, N., BELLAH, R., RABINOW, P.; SULLIVAN, W. (eds.). Social Science as Moral Inquiry. New York: Columbia, 1983. P. 360-381.

10. BELLAH, R. et al.. Appendix: Social Science as Public Philosophy. In: BELLAH, R. et al.. Habits of the Heart. Individualism and Commitment in American Life. Berkeley: California University Press, 1985. P. 297-307.

11. BENHABIB, S.. Critique, Norm, and Utopia: A Study of the Foundations of Critical Theory. New York: Columbia University Press, 1986. 
Sociologias, Porto Alegre, ano 17, no 39, mai/ago 2015, p. 60-109

12. BHASKAR, R.. The Possibility of Naturalism. A Philosophical Critique of the Contemporary Human Sciences. Brighton; Harvester, 1979.

13. BHASKAR, R.. Dialectic. The Pulse of Freedom. London: Verso, 1993.

14. BOLTANSKI, L.. Sociologie critique etsociologie de la critique. In : Politix, 3, 10-11, 1990, p. 124-134.

15. BOLTANSKI, L.; THÉVENOT, L.. The Reality of Expectations: A Sociology of Situated Judgment. In: Philosophical Explorations, 3, 2000, p. 208-231.

16. BOURDIEU, P.; CHAMBOREDON, J.C. ; PASSERON, J.C.. Le métier de sociologue: préalables épistémologiques. Paris: Mouton, 1973.

17. BOURDIEU, P.. Un actedésintéresséest-il possible? In: Raisons pratiques. Sur la théorie de I'action. Paris: Seuil, 1994. P. 174-167.

18. BURAWOY, M.. Presidential Address: For Public Sociology. In : American Sociological Review. 70, 1, 2005. p. 4-28.

19. CAILLÉ, A.. Anthropologiedudon. Le tiersparadigme. Paris: Desclée de Brouwer, 2005.

20. CAILLÉ, A.. Théorieanti-utilitaristedudon. Fragments d'une sociologiegénérale. Paris: La Découverte, 2009.

21. CAILLÉ, A.. La sociologiemalgré tout. Fragments d’une sociologiegénérale II. Paris: PressesUniversitaires de Nanterre. (forthcoming).

22. CAILLÉ, A.; VANDENBERGUE, F. Neo-classical Sociology. The Prospects of Social Theory Today. (forthcoming).

23. CAILLÉ, A.; LAZZERI, C. ; SENELLART, M. (eds.). Histoire raisonnée de la philosophie morale etpolitique. Le Bonheur etl'utile. Paris: La Découverte, 2001.

24. CANTO-SPERBER, M. (ed.). Dictionnaired'éthiqueet de philosophie morale. Paris: PUF, 1996.

25. CHANIAL, P.. La sociologie comme philosophie politique et réciproquement. Paris: La Découverte, 2011.

26. CHERNILLO, D.. The Natural Law Foundations of Modern Social Theory. Cambridge: Cambridge University Press, 2013.

27. DILTHEY, W.. Der Aufbau der geschichtlichen Welt in den Geisteswissenschaften. In: Gesammelte Schriften. Vol. VII. Göttingen: TeubnerVerlag, 1979.

28. DUBET, F.. Le travail des sociétés. Paris: Seuil, 2009.

29. DURKHEIM, E.. De la division du travail social. Paris: PUF, 1986. 
Sociologias, Porto Alegre, ano 17, no 39, mai/ago 2015, p. 60-109

30. DURKHEIM, E.. Les règles de la méthode sociologique. Paris: PUF, 1987.

31. FASSIN, D.. A Companion to Moral Anthropology. Oxford: Blackwell, 2012.

32. FERRARA, A.. Authenticity and the Project of Modernity. In: European Journal of Philosophy, 2, 3, 1994, p. 241-273.

33. FISCHOFF, E.. The Protestant Ethic and the Spirit of Capitalism. The History of a Controversy. In: Social Research, 11, 1, 1944, p. 53-77.

34. GIDDENS, A. (1982): Hermeneutics and Social Theory. In: Profiles and Critiques in Social Theory. London: MacMillan, 1981. P. 1-17.

35. GOULDNER, A.. For Sociology. Renewal and Critique in Sociology Today. Harmondsworth: Penguin, 1973.

36. GURVITCH, G.. Problèmes de la sociologie de la vie morale. In : Traité de sociologie, vol. 2. Paris: PUF, 1968. P. 137-172.

37. HAAN, N.; BELLAH, R.; RABINOW, P.; SULLIVAN, W. (eds.). Social Science as Moral Inquiry. New York: Columbia, 1983.

38. HABERMAS, J.. Theorie des kommunikativen Handelns. Vol. 1: Handlungsrationalität und gesellschaftliche Rationalisierung. Frankfurt am main: Suhrkamp, 1981.

39. HEGEL, F.W.. Grundlinien zur Philosophie des Rechts. In: Werke, vol. 7. Frankfurt am Main: Suhrkamp, 1970.

40. HEINICH, N.. La sociologie à l'épreuve des valeurs. In : Cahiers internationaux de sociologie, 121, 2, 2006, p. 287-315.

41. HITLIN, S.; VAISEY, S. (eds.). Handbook of the Sociology of Morality. New York: Springer, 2013.

42. HONNETH, A.. Das Andere der Gerechtigkeit. Aufsätzezurpraktischen Philosophie. Frankfurt am Main: Suhrkamp, 2000.

43. HONNETH, A. Verdinglichung. Frankfurt am Main: Suhrkamp, 2005.

44. ISAMBERT, F. ; LADRIÈRE, P. ; TERRENOIRE, J.. Pour une sociologie de l'éthique. In : Revue Française de Sociologie, 19, 3, 1978, p. 323-339.

45. ISAMBERT, F. (ed.). Sociologie de l'éthique. In: L'année sociologique, vol. 30, 1982.

46. JAYYUSI, L.. Values and Moral Judgement: Communicative Praxis as a Moral Order. In: BUTTON, G. (ed.). Ethnomethodology and the Human Sciences. Cambridge: Cambridge University Press, 1991. P. 227-251. 
47. KANT, I.. Grundlegungzur Metaphysik der Sitten. In: Werke, Vol 6, Part I. Darmstadt: Wissenschaftliche Buchgesellschaft, 1983.

48. LADRIÈRE, P.. Pour une sociologie de I’éthique. Paris: P.U.F, 2001.

49. LEVINE, D.. Visions of the Sociological Tradition. Chicago: Chicago University Press, 1995.

50. LOUCH, A.. Explanation and Human Action. Oxford: Blackwell, 1966.

51. LUKES, S.. The Social Construction of Morality? In: HITLIN, S.; VAISEY, S. (eds). Handbook of the Sociology of Morality. New York: Springer, 2013. P. 549560.

52. MACINTYRE, A.. A Short History of Ethics. New York: Macmillan, 1966.

53. MACINTYRE, A..After Virtue. A Study in Moral Theory. Notre Dame: Notre dame University Press, 1984.

54. MARX, K.. Die Deutsche Ideologie. In : Werke, vol. 3. Berlin: Dietz Verlag, 1969.

55. MAUSS, M.; FAUCONNET, P.. La sociologie: Objet et méthode. In: MAUSS, M.. Essais de sociologie. Paris: Minuit, 1969. P. 6-41.

56. MAUSS, M.. Essaisur le don. Forme et raison de l'échangedans les sociétés archaïques. In: Sociologieetanthropologie. Paris: PUF, 1989. P. 143-279.

57. MORIN, E.. La méthode. 2 vols. Paris: Seuil, 2008.

58. PARSONS, T.. Prolegomena to a Theory of Social Institutions. In: American Sociological Review, 55, 1990, p. 319-339.

59. PASCAL, B.. Pensées. In: Oeuvres completes (Pléiade). Paris: Gallimard, 1954.

60. PHARO, P.. Moraleetsociologie. Le senset les valeurs entre nature et culture. Paris: Gallimard, 2004.

61. RECKWITZ, A.. Toward a Theory of Social Practices. A Development in Culturalist Theorizing. In: European Journal of Social Theory, 5, 2, 2002, p. 243263.

62. RICOEUR, P.. Du texte à I'action. Essais d'herméneutique II. Paris: Seuil, 1986.

63. RICOEUR, P.. Soi-mêmecommeunautre. Paris: seuil, 1990.

64. SAYER, A.. The Moral Significance of Class. Cambridge: Cambridge University Press, 2005. 
65. SAYER, A. Why things matter to people. Social Science, values and ethical life. New York: Cambridge University Press, 2011

66. SCHELER, M.. Der Formalismus in die Ethik und die Materiale Wertethik. Neuer Versuchzur Grundlegungeinesethischen Personalismus. In: Gesammelte Werke, Vol. II. Bern: FranckeVerlag, 1980.

67. SCHLUCHTER, W.. Religion und Lebensführung. Band 1: Studienzu Max Webers Kultur und Werttheorie. Frankfurt am Main: Suhrkamp, 1991.

68. SELL, C. E.. Max Weber e a racionalização da vida. Petrópolis: Vozes, 2013. 69. SIMMEL, G.. Einleitung in die Moralwissenschaft, 2 vols. Frankfurt am Main: Suhrkamp, 1991.

70. SMITH, A.. The Theory of Moral Sentiments. Indianapolis: Liberty Classics, 1976.

71. SMITH, C.. Moral, Believing Animals: Human Personhood and Culture. Oxford: Oxford University Press, 2003.

72. STRAUSS, L.. Natural Right and History. Chicago: Chicago University Press, 1953.

73. TAYLOR, C.. Social Theory as Practice. In: Philosophical Papers 2: Philosophy and the Human Sciences. Cambridge: Cambridge University Press, 1985. P. 91-115.

74. TAYLOR, C.. Foreword. In: HONNETH, A.; JOAS, H.. Social Action and Human Nature. Cambridge: Cambridge University Press, 1988. P. VII - IX.

75. TAYLOR, C.. Sources of the Self. The Making of Modern Identity. Cambridge: Harvard university Press, 1989.

76. VANDENBERGHE, F.. Entre science et politique. La conjonction du positivisme et du décisionnisme dans la sociologie du droit de Max Weber. In : Revue Canadienne Droit et Société, 20, 1, 2005, p. 157-169.

77. VANDENBERGHE, F.. A fenomenologia como escada para o céu. Uma reconstrução crítica da epistemologia do amor de Max Scheler. In: MIGLIEVICH RIBEIRO, A. et al. (orgs.). A modernidade como desafio téorico. Ensaios sobre o pensamento social alemão. Porto Alegre: PUC-RS, 2008. P. 73-118.

78. VANDENBERGHE, F.. Metateoria, teoria social, teoria sociológica. In: VANDENBERGHE, F.. Uma historia filosófica da sociologia alemã. São Paulo: Annablume, 2012.

79. WEBER, M.. Die Objektivitätsozialwissenschaftlicher und sozialpolitischer Erkenntnis. In: Gesammelte Aufsätze zur Wissenschaftslehre. Tübingen: Mohr, 1988a. P. 46-214. 
Sociologias, Porto Alegre, ano 17, no 39, mai/ago 2015, p. 60-109

80. WEBER, M.. Der Sinn der 'Wertfreiheit' der soziologischen und ökonomischenWissenschaften. In: Gesammelte Aufsätzezur Wissenschaftslehre. Tübingen: Mohr, 1988b. P. 489-540.

81. WEBER, M.. Wissenschaft als Beruf. In: Gesammelte Aufsätze zur Wissenschaftslehre. Tübingen: Mohr, 1988c. P. 582-613.

82. WOLFE, A.. Whose Keeper? Social Science and Moral Obligation. Berkeley: University of California Press, 1989.

Recebido em: 10/09/2014

Aceite Final: 03/11/2014

http://dx.doi.org/10.1590/15174522-017003903 